\title{
The Flame Retardancy of Polyethylene Composites: From Fundamental Concepts to Nanocomposites
}

\author{
Erfan Rezvani Ghomi ${ }^{1, *}$, Fatemeh Khosravi ${ }^{1}$, Zahra Mossayebi ${ }^{1}$, Ali Saedi Ardahaei ${ }^{2}$, \\ Fatemeh Morshedi Dehaghi ${ }^{3}$, Masoud Khorasani ${ }^{4}$, Rasoul Esmaeely Neisiany ${ }^{5}{ }^{\circ}$, Oisik Das ${ }^{6, *}$, \\ Atiye Marani ${ }^{7}$, Rhoda Afriyie Mensah ${ }^{8}$, Lin Jiang ${ }^{8}$, Qiang Xu ${ }^{8}$, Michael Försth ${ }^{6}{ }^{6}$, \\ Filippo Berto ${ }^{9}$ and Seeram Ramakrishna ${ }^{1, *(\mathbb{C})}$
}

1 Center for Nanofibers and Nanotechnology, Department of Mechanical Engineering, Faculty of Engineering, National University of Singapore, Singapore 117576, Singapore; fatemeh_khosravi22@yahoo.com (F.K.); zhr.mossayebi@gmail.com (Z.M.)

2 Department of Polymer Engineering, Faculty of Engineering, Golestan University, P.O. Box 491888369, Gorgan 1575949138, Iran; alisaedi2012@yahoo.com

3 Department of Polymer Engineering and Color Technology, Amirkabir University of Technology, P.O. Box 15875-4413, Tehran 1591634311, Iran; morshedi.iut91@gmail.com

4 Department of Chemistry, Materials and Chemical Engineering “G. Natta”, Politecnico di Milano, Piazza Leonardo da Vinci 32, 20133 Milan, Italy; masoud.khorasani@mail.polimi.it

5 Department of Materials and Polymer Engineering, Faculty of Engineering, Hakim Sabzevari University, Sabzevar 9617976487, Iran; r.esmaeely@hsu.ac.ir

6 Structural and Fire Engineering Division, Department of Civil, Environmental and Natural Resources Engineering, Luleå University of Technology, 97187 Luleå, Sweden; michael.forsth@ltu.se

7 Baspar Sadaf Nab Sepahan, between 23 and 24 Streets, Mahmoodabad Industrial Town, Isfahan 8161199774, Iran; atiye.marani@gmail.com

8 School of Mechanical Engineering, Nanjing University of Science and Technology, Nanjing 210094, China; ramensah@ymail.com (R.A.M.); ljiang@njust.edu.cn (L.J.); xuqiang@njust.edu.cn (Q.X.)

9 Department of Mechanical and Industrial Engineering, Norwegian University of Science and Technology NTNU, S.P. Andersens Veg 3, 7031 Trondheim, Norway; filippo.berto@ntnu.no

* Correspondence: erfanrezvani@u.nus.edu (E.R.G.); oisik.das@ltu.se (O.D.); seeram@nus.edu.sg (S.R.)

Academic Editor: Pradip K. Bhowmik

Received: 12 October 2020; Accepted: 3 November 2020; Published: 5 November 2020

\begin{abstract}
Polyethylene (PE) is one the most used plastics worldwide for a wide range of applications due to its good mechanical and chemical resistance, low density, cost efficiency, ease of processability, non-reactivity, low toxicity, good electric insulation, and good functionality. However, its high flammability and rapid flame spread pose dangers for certain applications. Therefore, different flame-retardant (FR) additives are incorporated into PE to increase its flame retardancy. In this review article, research papers from the past 10 years on the flame retardancy of PE systems are comprehensively reviewed and classified based on the additive sources. The FR additives are classified in well-known FR families, including phosphorous, melamine, nitrogen, inorganic hydroxides, boron, and silicon. The mechanism of fire retardance in each family is pinpointed. In addition to the efficiency of each FR in increasing the flame retardancy, its impact on the mechanical properties of the PE system is also discussed. Most of the FRs can decrease the heat release rate (HRR) of the PE products and simultaneously maintains the mechanical properties in appropriate ratios. Based on the literature, inorganic hydroxide seems to be used more in PE systems compared to other families. Finally, the role of nanotechnology for more efficient FR-PE systems is discussed and recommendations are given on implementing strategies that could help incorporate flame retardancy in the circular economy model.
\end{abstract}

Keywords: flame retardancy; polyethylene; intumescent; fire; flammability 


\section{Introduction}

In recent times, polymers have been used in a wide range of industrial applications, such as packaging, electronics, and construction [1,2]. To better the performance of the aforementioned applications, polymers need to be more environmentally friendly, safe, and durable [3]. The utilization of polymers is encouraged due to good functionality, acceptable durability, and cost-efficiency; however, high flammability, and poor thermal properties are noticeable limitations for their applicability [4]. Most polymers are flammable and, by exposure to enough energy, they will leave a considerable amount of smoke and heat [5]. It is reported that annually about 5000 people in Europe and 4000 people in the United States are killed by fires. Furthermore, the economic loss of these fire accidents is estimated to be about $0.3 \%$ of the GDP [6]. Following the analysis conducted by Geneva-based Aircraft Crashes Record Office (ACRO), it is possible to reduce the possibility of fire catastrophes and their subsequent fatalities by reducing the flammability of polymeric materials [6]. Therefore, related to the use of polymers, there are environmental, economic, and health issues which are considered as the driving forces to motivate the conduction of research and different studies on the flammability of polymers [7].

Polyolefins are a group of the most popular polymers in various applications [8]. One of the main polymers of this group is PE, with more 100 million tons production per year, that is, $34 \%$ of total plastic market, and is extensively used due to good mechanical and chemical resistance, low density, cost efficiency, ease of processability, non-reactivity, low toxicity, good electric insulation, and good functionality [9]. However, like other polymers, the concern about PE is its flammability in applications requiring good flame retardancy. Although the emissions from PE have low toxicity, it has a low limiting oxygen index (LOI) and drips during burning, which causes rapid flame spread [10].

Typically, physical or chemical modifications, as well as applying FRs, are recommended to reduce the flammability of PE products [11]. Flame retardancy of polymers increases by incorporation of FRs and is estimated to triplicate their survival time in case of fire [12]. FRs are necessary as they enhance the flammability of polymeric materials by delaying the fire and it's spread [13]. The common commercial FRs used for PE systems are based on phosphorus, borate, inorganic hydroxides, silicon, and nitrogen and are introduced to polymer matrixes during processing [14]. Each of the FR approaches uses a different mechanism and their application is attributed the polymer matrix and the intended usage. For example, regarding the inorganic hydroxides, they will reduce the burning rate by releasing water to decrease the temperature since decomposition occurs at higher temperatures. Although gas-phase reactions are important in controlling flames in PE systems, quenching FRs based on halogens are not recommended due to environmental concerns [15]. Moreover, intumescent flame retardants (IFRs) are of great importance and efficiency in restricting the fire by forming a swollen char and are applicable for polymeric materials [16]. Considering the high production and applicability of $\mathrm{PE}$, the issue of its flammability is of great importance and hence, there is an urgent need to develop strategies that minimizes the flammability of PE.

A web search revealed that several review papers have been published on flame retardancy of polymers; however, there is a dearth of comprehensive research on FRs for PE composites [16,17]. Herein, this study reviews the specific approaches in enhancing flame retardancy of PE and some research papers published in the past 10 years, whiletaking into account the newly emerged FR nanocomposites.

\section{PE Grades and Properties}

PEs are one of the most potential materials of value-adding in case of accurate formulation modifications [18]. It is of great importance to know the grades of PE as their flame performance is correlated with their chemical structure (i.e., branching type) and FR formulations [18]. The structure and properties of PE main grades, including density, crystallinity, LOI, thermal conductivity, melting temperature, and molecular weight are summarized in Table 1. 
Table 1. Different properties of PE's grades [19-21].

\begin{tabular}{|c|c|c|c|c|c|c|c|}
\hline PE Grades & $\begin{array}{l}\text { Structure's } \\
\text { Description }\end{array}$ & $\begin{array}{l}\text { Density } \\
\left(\mathrm{g} / \mathrm{cm}^{-3}\right)\end{array}$ & Crystallinity & LOI (\%) & $\begin{array}{c}\text { Thermal } \\
\text { Conductivity } \\
(\mathrm{W} / \mathrm{m} \cdot \mathrm{K})\end{array}$ & $\begin{array}{c}\text { Melt } \\
\text { Temperature } \\
\left({ }^{\circ} \mathrm{C}\right)\end{array}$ & Mw (g/mol) \\
\hline $\begin{array}{c}\text { LDPE } \\
\text { (Low-density PE) }\end{array}$ & $\begin{array}{l}\text { Branched structure } \\
\text { containing long } \\
\text { and short chains }\end{array}$ & $0.915-0.932$ & $\begin{array}{l}\text { Lower degree } \\
\text { of crystallinity }\end{array}$ & $17-18$ & $0.32-0.35$ & $105-115$ & $<50,000$ \\
\hline $\begin{array}{c}\text { LLDPE } \\
\text { (Linear low-density PE) }\end{array}$ & $\begin{array}{l}\text { Branched structure } \\
\text { containing } \\
\text { short chains }\end{array}$ & $0.910-0.930$ & $\begin{array}{l}\text { Slightly higher } \\
\text { than LDPE }\end{array}$ & $17-18$ & $0.35-0.45$ & $120-130$ & $<50,000$ \\
\hline $\begin{array}{c}\text { HDPE } \\
\text { (High-density PE) }\end{array}$ & Linear structure & $0.940-0.970$ & $\begin{array}{l}\text { Higher degree } \\
\text { of crystallinity }\end{array}$ & $17-18$ & $0.45-0.5$ & $128-136$ & Up to 200,000 \\
\hline
\end{tabular}

\section{FR Approaches and Materials}

In this section, the specific approaches and materials used for enhancing the flame retardancy of the PE systems are discussed and their recent works are investigated.

\subsection{Phosphorous and Melamine}

Phosphorus-based FRs are the most considerable halogen-free type of FRs used for improving flame retardancy of PE. Common phosphorus-based FRs include red phosphorus (RP), phosphine oxides, phosphines, phosphonates, phosphates, ammonium phosphate, and phosphites $[19,20]$. Regarding the PE structure, phosphorus compounds are more advantageous in comparison with the halogen-based FRs as they work in two separate phases, gas and condense [21]. The physical and chemical reactions mostly affect flame inhibition and heat reduction because of the controlling melt flow, surface protection by acids, char layer promotion, and char layer protection against oxidation. Phosphorus FRs volatilize into the gas phase and strongly scavenge the hydrogen and hydroxyl radicals [22]. The Equations (1)-(5) demonstrates the radical scavenging of $\dot{\mathrm{H}}$ and $\dot{\mathrm{OH}}$ by the active phosphorus radicals such as $\mathrm{PO}$ and $\mathrm{HPO}_{2}$, which are present in the flame (M is a third body species) [21].

$$
\begin{gathered}
\mathrm{HPO}_{2}+\dot{\mathrm{H}} \rightarrow \mathrm{PO}+\mathrm{H}_{2} \mathrm{O} \\
\mathrm{HPO}_{2}+\dot{\mathrm{H}} \rightarrow \mathrm{PO}_{2}+\mathrm{H}_{2} \\
\mathrm{HPO}_{2}+\mathrm{OH} \rightarrow \mathrm{PO}_{2}+\mathrm{H}_{2} \mathrm{O} \\
\mathrm{PO}+\dot{\mathrm{H}}+\mathrm{M} \rightarrow \mathrm{HPO}+\mathrm{M} \\
\mathrm{PO}+\mathrm{O} \dot{\mathrm{H}}+\mathrm{M} \rightarrow \mathrm{HPO}_{2}+\mathrm{M}
\end{gathered}
$$

The produced HPO can effectively quench the flame and lower the reactivity of the material compared to $\dot{\mathrm{H}}$ and $\mathrm{OH}$. Some phosphorus-containing compounds can decompose to phosphoric acid and polyphosphoric acid in the condense phase. A molten viscous layer formed by acids protect the surface of the polymers and restrict oxygen penetration [22,23]. Ammonium polyphosphate (APP) has been broadly used in IFR systems as an acidic source and blowing agent. Khanal et al. [24] prepared a novel IFR system containing APP and tris (2-hydroxyethylene) isocyanurate (THEIC) to enhance the fire and flammability performance of HDPE. Flammability of the prepared HDPE/IFR (AAP/THEIC) composite was evaluated by LOI analysis and cone calorimeter tests (CCT) indicating different parameters, but just one of them is investigated, which is peak heat release (PHR) rate here. The LOI analysis indicated that the LOI value of the HDPE/IFR composite with the weight ratio of 3:1 was higher than the LOI value of the pure HDPE and HDPE/APP. It is evident that adding THEIC as a char agent increased the flame retardancy of HDPE/IFR composite while the most striking feature was the optimum weight ratio of APP (3) to THEIC (1). The LOI value of the composite decreased by increasing the amount of THEIC. The CCT analysis illustrated that the combustion time of HDPE/IFR composite is slower than the pure HDPE and the PHR rate decreased and occurred at a longer time. 
It is clear that the charring formation attributing to THEIC component caused a significant reduction of PHR rate value.

Melamine (MLM) is another unique material containing $67 \mathrm{wt} . \%$ nitrogen and excellent thermal resistance, which could be combined with phosphorus compounds used in FR applications. Among the MLM-containing compounds, MLM phosphate is specific due to the presence of phosphorus. Other commercially available MLM-based FRs are melamine cyanurate (MC), melamine pyrophosphate (MP), and melamine polyphosphate (MPP). Moreover, MLM can form salts with high thermal stability and strong acids. Salasinksa et al. [4] evaluated the effect of incorporating copper phosphate and melamine phosphate (CUMP) into HDPE as a FR compound and compared it with HDPE/APP. The fire property of HDPE containing CUMP was carried out by CCT. Figure 1 indicates the scanning electron microscope (SEM) images of PE/APP and PE/CUMP formed char layer, as well as char chemical composition.
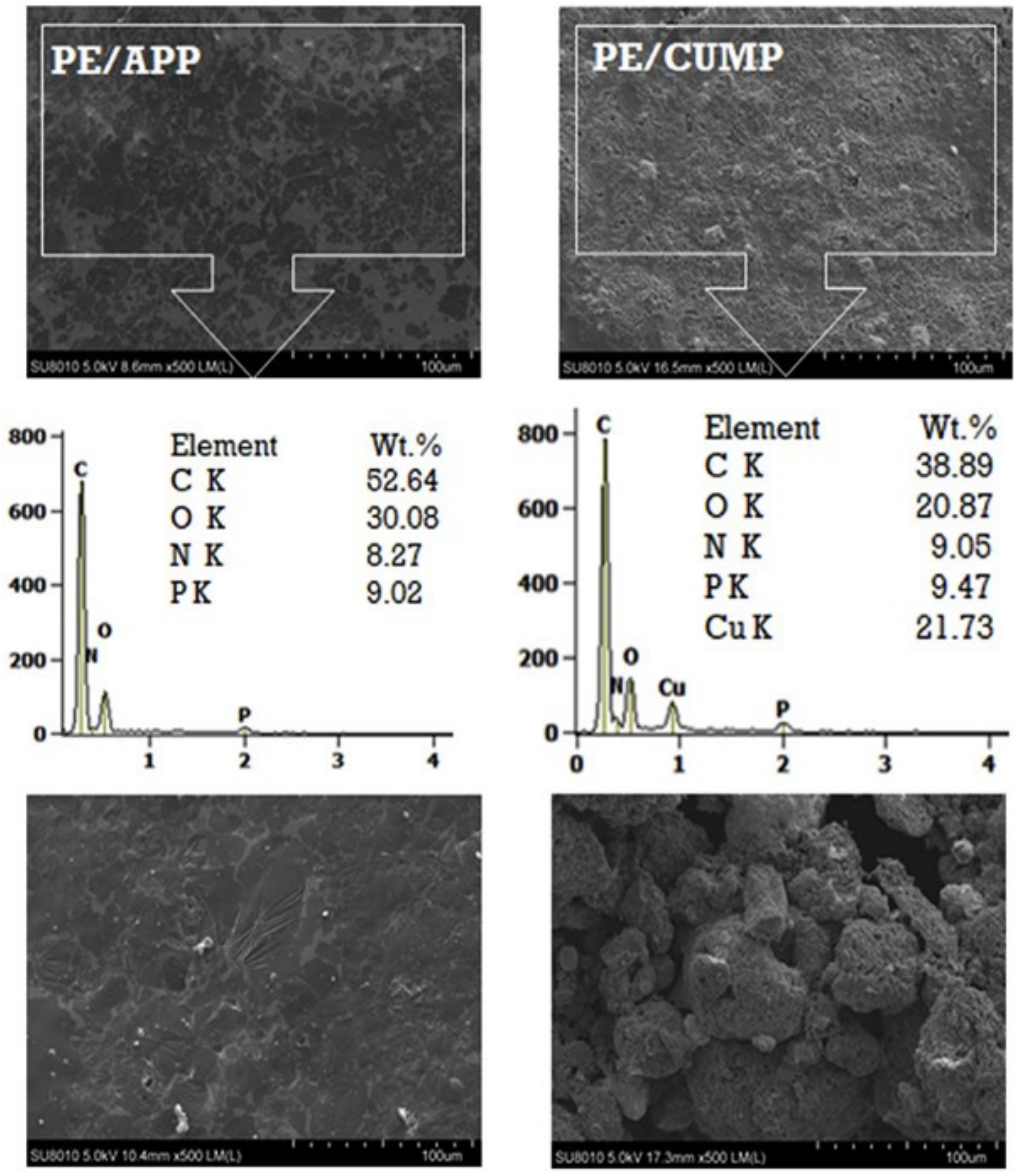

Figure 1. SEM images of cone calorimetry residues of Polyethylene/Ammonium polyphosphate (PE/APP) (outer and inner) and Polyethylene/Copper phosphate and melamine phosphate (PE/CUMP) (outer and inner), reprinted with permission from Ref. [4].

The SEM images of the residues CCT conducted on HDPE/APP and HDPE/CUMP samples confirmed the char formation of both. Regarding the HDPE/APP, the formed char layer was thin without swollen structure while HDPE/CUMP was found to be porous inside char. The chemical composition analysis demonstrated that the char layer composed of $\mathrm{C}, \mathrm{O}, \mathrm{N}$, and $\mathrm{P}$ components. CUMP were likely to be decomposed to $\mathrm{CuO}$ and $\mathrm{P}_{2} \mathrm{O}_{7}$, and then take part in the crosslink process, which finally causes a dense char layer formation and mechanical behavior improvement. It was evident that the HDPE/CUMP resulted in more char formation in comparison with pure HDPE. Compared to pure HDPE, HDPE/CUMP showed a significant reduction in PHR rate. Furthermore, the CUMP worked in both condense and gas-phase via char layer formation and emission of more 
non-flammable gases, respectively. Other works on the flame-retardancy of PE using phosphorous and MLM compounds have been summarized in Table 2.

Table 2. Recent studies on flame retardancy of PE using phosphorus, melamine, and nitrogen.

\begin{tabular}{|c|c|c|c|c|}
\hline Polymer Matrix & Additive(s) & Mechanism(s) & Result(s) & Ref. \\
\hline HDPE & CUMP & $\begin{array}{l}\text { Char formation, Emission of } \\
\text { non-flammable gases }\end{array}$ & $\begin{array}{l}\text {-Reduction of decomposition rate } \\
\text {-Increasing the yield of residue } \\
\text {-Reduction of heat release rate (HRR) } \\
\text {-Increasing the time of burning }\end{array}$ & [4] \\
\hline HDPE & $\begin{array}{l}\text { APP } \\
\text { THEIC }\end{array}$ & Char forming & $\begin{array}{l}\text {-HDPE/APP/THEIC showed the heist } \\
\text { LOI value } \\
\text {-IFR incorporation significantly declined } \\
\text { the PHR rate of HDPE }\end{array}$ & [24] \\
\hline LDPE & $\begin{array}{l}\text { Carbonization agent, } \\
\text { APP, MP }\end{array}$ & $\begin{array}{l}\text { Char formation, Physical barrier } \\
\text { creation able to deactivate the } \\
\text { oxidation-active centers of carbon }\end{array}$ & $\begin{array}{l}\text {-Optimal flame retardancy belongs to } \\
\text { carbonization agent/APP/MP with the } \\
\text { weight ratio of } 7: 7: 1 \\
\text {-Increasing the maximum temperature of } \\
\text { the decomposition peak of LDPE }\end{array}$ & [10] \\
\hline LDPE & $\begin{array}{l}\text { APP, Pentaerythritol } \\
\text { (PER), Salt of MP, } \\
\text { Dibromoneop-enty } \\
\text { Glycol (DBNPG) }\end{array}$ & Char forming, Thermal barrier & $\begin{array}{l}\text {-Improving the char layer } \\
\text {-Thermal barrier behavior enhancement } \\
\text {-Increase in melt viscosity with proper } \\
\text { amount of DBNPG }\end{array}$ & [25] \\
\hline PE & $\begin{array}{l}\text { Poly (piperazine } \\
\text { methylphosphonic acid } \\
\text { pentaerythritol ester) }\end{array}$ & $\begin{array}{l}\text { Char formation, } \\
\text { Exert condensed phase }\end{array}$ & $\begin{array}{l}\text {-Improvement the residual mass and } \\
\text { thermal stability } \\
\text {-Reduction in HRR, THR } \\
\text {-UL-94 V0 rating }\end{array}$ & [26] \\
\hline LDPE & APP, PER, MLM & Char formation & -Increasing in thermal stability & [27] \\
\hline LDPE & PSPHD-SEP & Vapor phase radical-trapping effect & $\begin{array}{l}\text {-Reduction in PHR rate, THR } \\
\text {-Improving the thermal stability } \\
\text {-Increasing the LOI value (21\%) compared } \\
\text { to neat LDPE } \\
\text {-UL-94 V-2 rating }\end{array}$ & [28] \\
\hline HDPE & $\begin{array}{l}10 \mathrm{wt} . \% \text { of mono } \\
\text { ammonium phosphate } \\
\text { (MAP), ammonium } \\
\text { zeolite (AZ), } \\
\text { and microcrystalline } \\
\text { cellulose (MCC) }\end{array}$ & Char forming & $\begin{array}{l}\text {-Slowing down the burning rates of } \\
\text { HDPE/MAP10 and } \\
\text { HDPE/MCC/MAP } 5 / \text { AZ5 composite by } \\
64 \% \text { and } 62 \% \text {, respectively } \\
\text {-Improving the LOI level and char } \\
\text { forming by incorporating FRs }\end{array}$ & [29] \\
\hline LDPE & $\begin{array}{c}\text { THEIC, } \\
\text { microencapsulated } \\
\text { ammonium } \\
\text { polyphosphate (MCAPP) }\end{array}$ & Formation of a compact char & $\begin{array}{l}\text { In the composite with MCAPP/ } \\
\text { THEIC (2:1): } \\
\text {-Achieving V-0 rating of UL- } 94 \\
\text {-Reduction in PHR rate and THR by } 74.8 \% \\
\text { and } 71.9 \% \text {, respectively compared to } \\
\text { pure LDPE } \\
\text {-Enhancing thermal stability at } \\
\text { high temperature }\end{array}$ & [30] \\
\hline $\begin{array}{l}\text { PE/Wood } \\
\text { Flour (WF) }\end{array}$ & APP & $\begin{array}{l}\text { Performance of WF as the charring } \\
\text { agent with incorporation IFRs }\end{array}$ & $\begin{array}{l}\text {-Achieving V-0 rating of UL- } 94 \\
\text {-Positive effect of IFRs and WF to control } \\
\text { the fire spreading and the risk } \\
\text { of combustion } \\
\text {-Reduction in PHR rate of the composites } \\
\text { containing IFRs and compatibilizers }\end{array}$ & [31] \\
\hline $\mathrm{PE}$ & $\begin{array}{l}\text { Phenyl phosphinic arid } \\
\text { di-4-[1-(4-pheny } \\
\text { phodphonic acid } \\
\text { monophenyl } \\
\text { ester-yl)-methyl-ethyl] } \\
\text { phenyester } \\
\text { dimelaminium } \\
\text { (PDEPDM) }\end{array}$ & Char forming & $\begin{array}{l}\text { In composite containing } \\
32 \mathrm{wt} \% \text { PDEPDM: } \\
\text {-Achieve in V-0 rating of UL- } 94 \\
\text {-Improvement in LOI, formation of } \\
\text { char residue } \\
\text {-Increase in char yield from } 0.08 \mathrm{wt} \% \text { for } \\
\text { neat PE to } 5.17 \mathrm{wt} . \% \text { for composite } \\
\text { containing } 40 \mathrm{wt} \% \text { PDEPDM at } 800{ }^{\circ} \mathrm{C} \\
\text {-Reduction in tensile and impact strength }\end{array}$ & [32] \\
\hline LDPE & $\begin{array}{l}\text { Expandable graphite } \\
\text { (EG), Ethylenediamine } \\
\text { phosphate (EDAP), } \\
\text { 3,5-diaminobenzoic acid } \\
\text { phosphate (DABAP) }\end{array}$ & $\begin{array}{l}\text { Releasing } \mathrm{CO}_{2} \text { gas acting as an } \\
\text { effective charring effect }\end{array}$ & $\begin{array}{l}\text {-Substantial reductions in PHR rate for all } \\
\text { flame-retarded samples } \\
\text {-Decreasing the mass loss rate by adding } \\
\text { intumescent additives }\end{array}$ & [33] \\
\hline LLDPE & $\begin{array}{l}\text { MLM salt of } \\
\text { pentaerythritol } \\
\text { phosphate } \\
\text { montmorillonite } \\
\text { (MPPM) }\end{array}$ & thermally stable char forming & $\begin{array}{l}\text {-Enhancing the char formation and the } \\
\text { thermal stability of LLDPE at } \\
\text { high temperatures } \\
\text {-Substantial reduction in PHR rate, THR, } \\
\text { mean mass loss rate, and fire growth } \\
\text { rate index } \\
\text {-Achieving V-0 rating in UL-94V test }\end{array}$ & [34] \\
\hline
\end{tabular}


Table 2. Cont.

\begin{tabular}{|c|c|c|c|c|}
\hline Polymer Matrix & Additive(s) & Mechanism(s) & Result(s) & Ref. \\
\hline LLDPE & $\begin{array}{l}\text { MLM salt of chitosan } \\
\text { phosphate (MCHP), } \\
\text { Organically modified } \\
\text { montmorillonite } \\
\text { (OMMT) }\end{array}$ & -Char forming & $\begin{array}{l}\text {-Increasing the char residue } \\
\text {-Improving the thermal stability } \\
\text {-Reduction of PHR rate, total heat release } \\
\text { (THR), } \mathrm{CO}, \mathrm{CO}_{2} \text { emissions and fire } \\
\text { growth index (FGI) }\end{array}$ & [35] \\
\hline HDPE & $\begin{array}{l}\text { APP, PER, modified } \\
\text { porous mesostructured } \\
\text { silica (SBA-15) }\end{array}$ & Intumescent char layer formation & $\begin{array}{l}\text {-Better flammability characteristics at low } \\
\text { SBA-15 loadings }(<2 \text { wt.\%) } \\
\text {-Enhancement in fire properties affected } \\
\text { by formation of crystalline silicone } \\
\text { phosphate barrier }\end{array}$ & [36] \\
\hline LDPE & $\mathrm{RP}, \mathrm{APP}$ & Intumescent char layer formation & $\begin{array}{l}\text {-Increase in LOI value from } 17.5 \text { to } 24.2 \text { by } \\
\text { addition of } 30 \mathrm{wt} \% \text { APP } \\
\text {-The highest LOI value of } 27.2 \text { and UL- } 94 \\
\text { rating of V0 at ratio of } 5: 1 \text { (APP:RP) } \\
\text {-Increase in the gas phase action by the } \\
\text { addition of RP }\end{array}$ & [37] \\
\hline HDPE & APP, MLM & Intumescent char layer formation & $\begin{array}{l}\text {-Improvement in the composite's tensile } \\
\text { strength and combustion process by FR } \\
\text { loading's increase } \\
\text {-Improving the thermal stability and char } \\
\text { formation's promotion by FRs }\end{array}$ & [38] \\
\hline $\mathrm{PE}$ & $\begin{array}{l}\text { Pentaerythritol } \\
\text { phosphate nickel salt } \\
\text { (PPNS), APP }\end{array}$ & Intumescent char layer formation & $\begin{array}{l}\text { - LOI value increased from } 30 \% \text { to } 34 \% \\
\text {-Reduction in total HRR by } 46.3 \% \\
\text { and } 51.9 \% \\
\text {-Reduction in average mass loss rate by } \\
40.6 \text { and } 87.5 \%\end{array}$ & [39] \\
\hline HDPE/WF & $\begin{array}{l}\text { APP, Aluminum } \\
\text { trihydroxide }(\mathrm{ATH}) \\
\mathrm{SiO}_{2}, \mathrm{CaCO}_{3}\end{array}$ & Char forming & $\begin{array}{l}\text {-Increase in both mechanical and fire } \\
\text { properties by using nanofiller additive } \\
\text {-Combination of APP and } \mathrm{SiO}_{2} \text { showed } \\
\text { the highest LOI value, and the } \\
\text { lowest HRR }\end{array}$ & [40] \\
\hline PE & DABAP, EDAP, EG & Char forming & $\begin{array}{l}\text {-Higher decomposition temperature was } \\
\text { attributed to DABAP } \\
\text {-The best char yields was belonged to } \\
\text { PE/DABAP } \\
\text {-PE/EDAP/EG showed the best flame } \\
\text { retardancy behavior }\end{array}$ & [41] \\
\hline HDPE/WF & APP & Char forming & $\begin{array}{l}\text {-APP decreased HRR and total smoke } \\
\text { values of system } \\
\text {-The heat of ignition remained constant } \\
\text {-Maximum reduction of HRR obtained by } \\
\text { increasing the amount of APP to } 4 \mathrm{wt} . \%\end{array}$ & [42] \\
\hline HDPE & $\begin{array}{l}\text { Phosphorous-nitrogen- } \\
\text { based charring } \\
\text { agent (PDTBP), APP }\end{array}$ & $\begin{array}{l}\text { Intumescent char } \\
\text { layer formation }\end{array}$ & $\begin{array}{l}\text {-UL- } 94 \text { V-0 rating } \\
\text {-Low migration percentage }(2.2 \%) \\
\text {-Decrease in PHR rate, THR, and fire } \\
\text { hazard value } \\
\text {-High tensile and flexural strength }\end{array}$ & [43] \\
\hline LLDPE & $\begin{array}{l}\text { MLM salt of } \\
\text { montmorillonite } \\
\text { phosphate (MMP), } \\
\text { zinc borate (ZB) }\end{array}$ & Char layer formation & $\begin{array}{l}\text {-Increasing in thermal stability and } \\
\text { char formation } \\
\text {-Reduction in PHR rate, mean HRR, THR, } \\
\text { and mean mass loss rate } \\
\text {-Reduction in the fire risk } \\
\text {-UL- } 94 \text { V-0 rating for the composite with } \\
30 \text { wt. } \% \text { MMP and } 5 \text { wt. } \% \text { ZB } \\
\text {-Highest char residue formation for the } \\
\text { composite with } 32 \text { wt. } \% \text { MMP and } \\
3 \text { wt. } \% \text { ZB } \\
\text {-Max. fire performance index }(142 \%) \text { for } \\
\text { the system with only MMP }(40 w t . \%)\end{array}$ & [44] \\
\hline $\begin{array}{l}\text { Ethylene-vinyl } \\
\text { acetate } \\
\text { (EVA)/LLDPE }\end{array}$ & $\begin{array}{l}\text { MLM, TRZ, and } \\
\text { Bentonite Clay }\end{array}$ & $\begin{array}{l}\text { Strengthening the protective char } \\
\text { barrier produced by ATH }\end{array}$ & $\begin{array}{l}\text { E-PE/120ATH in comparison with the } \\
\text { conventional E-PE/185ATH achieved: } \\
\text {-Self-extinguishing behavior } \\
\text { (UL-94 V-0 rating) } \\
\text {-Reduction in the stiffness and } \\
\text { improvement in elongation at break, } \\
\text { Composites with TRZ and clay showed } \\
23 \% \text { reduction in PHR rate and } 11 \% \text { in } \\
\text { smoke production }\end{array}$ & [45] \\
\hline LDPE/WF & APP, WF & Char forming & $\begin{array}{l}\text { Increasing the LOI value from } 17.5 \text { to } 24.2 \\
\text { with addition of } 30 \mathrm{wt} \text {. } \% \text { m-APP } \\
25 \% \text { reduction in THE in the } \\
\text { LDPE/WF/APP. }\end{array}$ & [46] \\
\hline
\end{tabular}




\subsection{Nitrogen}

Nitrogen-based FRs have also been used in PE systems to improve its flame resistance. Essential environmentally friendly groups of FRs are nitrogen-comprising ones because of their low toxicity, efficiency, recyclability, and their low evolution of smoke during combustion $[47,48]$. Commonly known nitrogen-based FRs are ammonia, MLM, and their derivatives, whilst other types based on urea and guanidine are also identified. Generally, MLM and derivatives are the basic components of an intumescent system [49,50]. Nitrogen-containing compounds showed a well-effective synergism with the fire retardants containing phosphorus [51]. As a case in point, MP and APP materials, taking advantage of N-P synergism, are the most used $\mathrm{P}$ and N-containing fire retardants. Besides, MLM/ammonium salts with organic or inorganic acids such as boric acid (BA), cyanuric acid, phosphoric acid, or pyro/poly-phosphoric acid are typically used to provide higher thermal stability along with lower volatility [52]. Polymeric nitrogen compounds based on cyanuric acid have been recently developed and $\mathrm{MC}$, as a two-dimensional, highly thermally stable structure, showed strong synergism with phosphorus compounds $[53,54]$.

The flame retardancy action mode of MLM and its salts is somewhat different [55]. Upon heating of the pure MLM, MLM starts volatilization by heat absorption caused by cooling down the surface of the polymeric matrix. Under high temperature, MLM undergoes further endothermic decomposition to produce cyanamid [56]. In the meanwhile, thermally stable condensates, i.e., melam, melem, and melon, as well as ammonia gas, may form. The chemical structure of the produced condensates is illustrated in Figure 2. These residue condensates contribute to the creation of an insulative layer in the condensed-phase. In addition, the ammonia evolution dilutes the burning atmosphere with inert/non-combustible gases, causing a gas phase flame retardancy contribution. In MLM salts, if MLM reforms upon dissociation of the salts exposed to the heat, a same decomposition mechanism is expected. Because of more progressive condensation in MLM salts rather than the pure MLM, their condensed-phase contribution is dominant [57]. Likewise, $\mathrm{N}$-containing synergistic systems either form char through condensed-phase or promote gas phase reaction to scavenge free radicals [52,58]. Moreover, the ammonium salts decrease the spread rate of the flame but evolve potentially toxic gases [58].

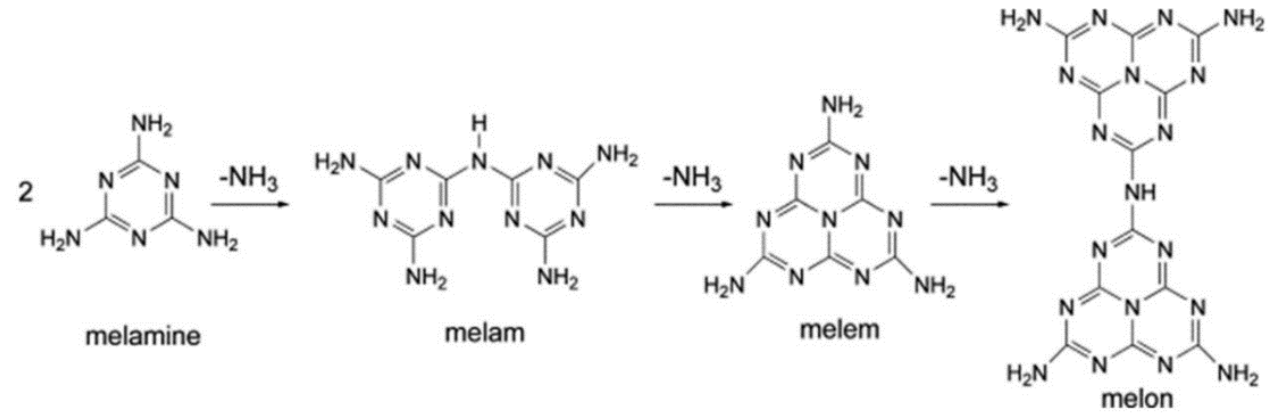

Figure 2. Chemical structure of the condensates produced through endothermic thermal decomposition of the melamine, reprinted with permission from Ref. [55].

In an interesting study reported by Luyt et al. [18], six FR compositions obtained by mixing commercial N- and P-containing FRs were embedded into different grades of LDPE and LLDPE to evaluate their effects on thermal stability and fire-resistance. LDPE grade produced in an autoclave reactor showed the best flame retardancy performance (UL $94 \mathrm{V0}$, char residue: $10 \pm 1 \%$ at $800{ }^{\circ} \mathrm{C}$ ) when $35 \mathrm{wt} . \%$ of the triazine (TRZ) derivative and APP formulated FR was incorporated. This was due to the phosphorus-nitrogen synergism forming the highly thermally stable phosphorous oxynitride residue. In contrast, LDPE from the tubular reactor and LLDPE, contained TRZ derivative and APP formulated FR, represented poorer fire resistance since their strongly entangled molecules hindered well dispersion of FRs and lessened their activity due to the premature thermal decomposition. Results of 
the nitrogen-based FR revealed that nitrogen-based compounds alone could not achieve a V0 rating in any grades of PE. Table 2 indicates the works conducted by using nitrogen-based FRs in PE systems during the past 10 years.

The nitrogen and phosphorus-based flame retardants used as treatments in PE, LDPE, LLDPE, and HDPE are listed in Table 2 with emphasis on the effect each additive have on the polymer matrix. Meanwhile, some additives greatly improve the flame retardancy of the polymeric composites others, such as the Phenyl phosphinic arid di-4-[1-(4-pheny phodphonic acid monophenyl ester-yl)-methyl-ethyl] phenyester dimelaminium (PDEPDM), caused a reduction in the mechanical properties of PE. Hence, it is more appropriate to apply FRs that enhance fire properties without compromising their mechanical properties.

\subsection{Inorganic Hydroxides}

Inorganic hydroxides are widely applied to develop the fire retardancy of PE products because of their benefits, such as low toxicity, cost efficiency, minimal corrosion, and contribution to declining smoke emission during the combustion process. In addition, releasing water at the temperature above $200{ }^{\circ} \mathrm{C}$ is a distinct characteristic of inorganic compounds. The two main types of inorganic hydroxide are ATH and magnesium hydroxide $(\mathrm{MH})$. There are typically two mechanisms of action in flame retardancy of $\mathrm{ATH}$ and $\mathrm{MH}$ compounds including flame dilution and the catalytic effect, which leads to charring enhancement [59]. The anhydrous alumina and magnesia are white powerful refractor powders, which can reflect the heat and assist to improve heat insulation with aggregating on the surface. Regarding the ATH, water releasing occurs at $220^{\circ} \mathrm{C}$, while $\mathrm{MH}$ releases water at $330{ }^{\circ} \mathrm{C}$. The largest commercially use of ATH and MH FRs is in wire and cable insulation applications. There are several advantages associated with ATH, such as low cost, non-toxicity, and excellent flammability behavior. Generally, flame retardancy analysis requires at least 35\% of metal hydroxide. Increasing the amount of metal hydroxide could lead to degrading physical properties as well as low-temperature flexibility. As a result, one of the most important techniques is to combine metal hydroxides with other FRs, such as phosphorus compounds, boron compounds, and nanoclays [60,61]. In some cases, surface modification is effective to increase flame retardancy of hydroxide compounds. Moreover, ATH is able to work in two different phases, gas and condense. The main mechanism of ATH in the condensed phase is heat absorption during the decomposition process. The ATH decomposition occurs at the range of $220-400{ }^{\circ} \mathrm{C}$ based on the reaction as shown in Equation (6) [62].

$$
2 \mathrm{Al}(\mathrm{OH})_{3} \rightarrow \mathrm{Al}_{2} \mathrm{O}_{3}+3 \mathrm{H}_{2} \mathrm{O}
$$

The decomposition reaction of ATH is extremely endothermic and absorbs about $1 \mathrm{~kJ} / \mathrm{gr}$ heat. The heat absorption reaches its maximum at $300{ }^{\circ} \mathrm{C}$. The most striking feature is the formation of water vapor from the hydroxyl groups bonded to aluminum. Furthermore, the combustion is hindered by releasing the water vapor into the fire, diluting the flammable gases concentration, and limiting the accessibility of oxygen to the surface of the composite [62]. On the contrary, to the halogenated-FRs, the produced gases from the decomposition reaction of ATH are non-toxic and non-corrosive. Generally, the required characteristics of inorganic hydroxides FRs in commercial products are: (a) low cost, (b) highly accessible with low surface area and small particle size, (c) low toxicity, (d) exhibiting endothermic decomposition reaction between $100-300{ }^{\circ} \mathrm{C},(\mathrm{e})$ capable of being used at high loading, and (f) colorless [22].

Layered double hydroxides (LDH) are synthetic materials containing negatively charged layers of inorganic/organic anions, which alternately located in the interlayer of positively charged layered of metal hydroxide $[63,64]$. The general formula of LDH is presented in Equation (7) [64].

$$
\left[\mathrm{M}_{1-\mathrm{x}}^{2+} \mathrm{M}_{\mathrm{x}}^{3+}(\mathrm{OH})_{2}\right]^{\mathrm{x}+} \mathrm{A}_{\frac{\mathrm{x}}{\mathrm{n}}}^{\mathrm{n}-} \mathrm{yH} \mathrm{H}_{2} \mathrm{O}
$$


$\mathrm{LDH}$ is considerably important to be used in commercial polymer industries, as they are environmentally friendly FRs. These types of FR compounds are attractive due to their endothermic decomposition against high temperature, nontoxicity, and high level of smoke suppression [64,65]. Until now, various studies have been conducted to evaluate the effect of incorporating metal hydroxides with polymers and nanocomposites.

Arslan et al. [66] investigated the result of using metal hydroxide, ZB, MLM, APP, and PER as reinforcements to improve flammability of LDPE/Polylactic acid (PLA). The efficiency of flame retardancy of the composites was evaluated by LOI analysis. The results showed the higher LOI values for samples containing MLM, APP, and PER. The LOI values of LDPE/PLA/ZB, LDPE/PLA/AH, LDPE/PLA/MH, LDPE/PLA/MLM, and LDPE/PLA/APP were 21.3, 20.2, 21.4, 20.4, and 22.3, respectively. As can be observed, the compound of $\mathrm{ZB}, \mathrm{AH}, \mathrm{MH}$, and MLM indicated a negative impact on flammability of the LDPE/PLA blend. The highest value of LOI analysis was attributed to LDPE/PLA/APP30/PER15/MLM15/ZB3 composite with 95.17\% improvement in comparison to the LDPE/PLA blend. The best flame retardancy results were reported in Figure $3 \mathrm{a}$. It is crystal clear that APP is the most effective FR, which significantly promoted the flame behavior of LDPE/PLA. In addition, APP/MLM/PER incorporation considerably increased the strength and integrity of the char layer due to the promotion of phosphor and oxygen. Figure 3 demonstrates the images of char layer after LOI analysis and char residue of LDPE/PLA/APP/MLM/PER composite.
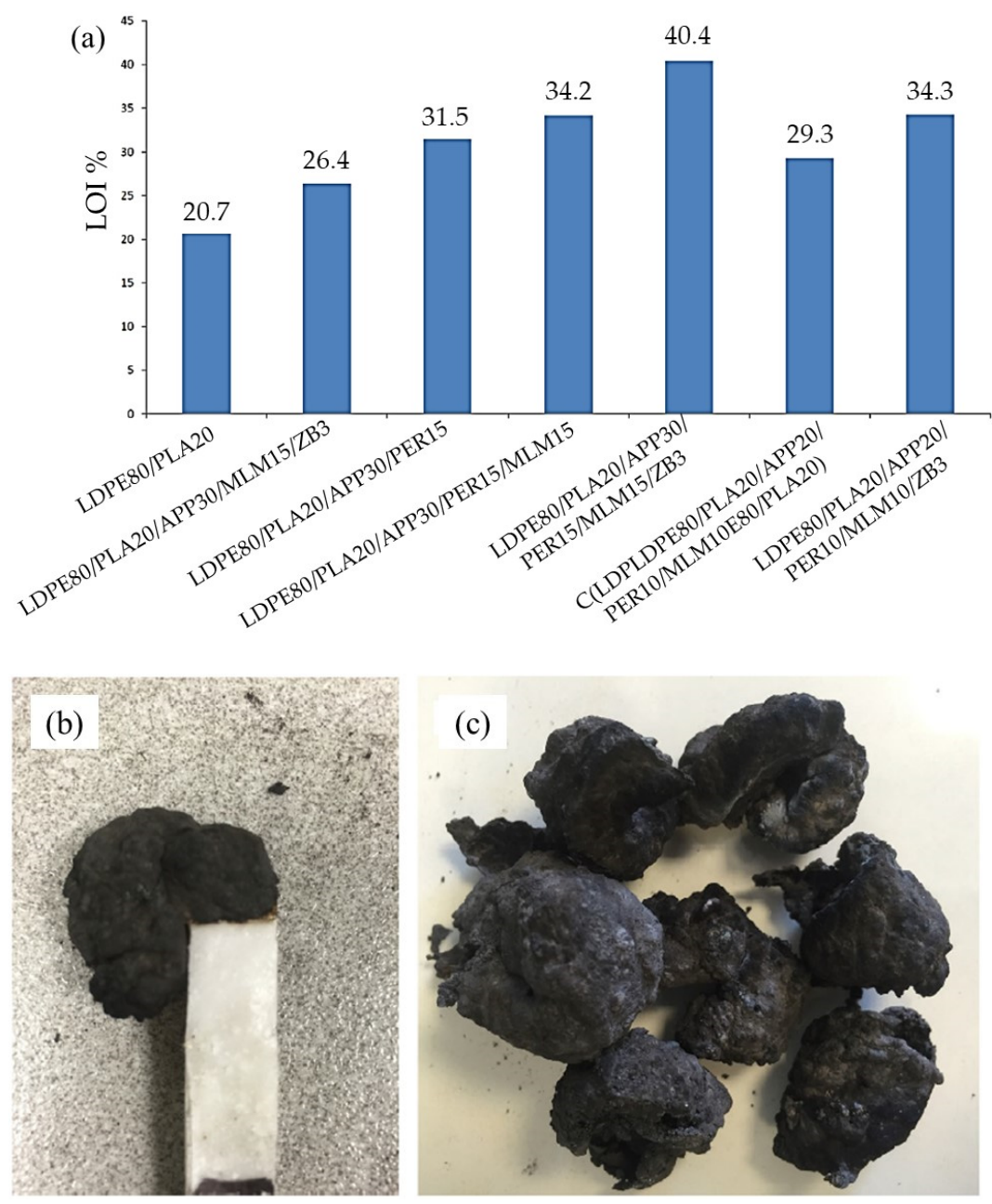

Figure 3. (a) Limiting oxygen index (LOI) values of all samples, images of (b) char of the LDPE/PLA/APP/MLM/PER after the LOI analysis, and (c) char residue of the LDPE/PLA/APP/MLM/PER, reprinted with permission from Ref. [66]. 
Recent studies on the flame-retardancy of PE using inorganic hydroxides have been summarized in Table 3.

Table 3. Recent studies on flame retardancy of PE using inorganic hydroxides.

\begin{tabular}{|c|c|c|c|c|}
\hline Polymer Matrix & Additive(s) & Mechanism(s) & Result(s) & Ref. \\
\hline HDPE & MH, Modified MH & $\begin{array}{l}\text { Char forming with both } \mathrm{MH} \\
\text { and modified } \mathrm{MH}\end{array}$ & $\begin{array}{l}\text {-The flame sustainability of } \\
\text { HDPE/modified MH was higher } \\
\text { than HDPE/MH } \\
\text {-The flame retardancy behavior of } \\
\text { HDPE/modified MH did not enhance } \\
\text { compared to HDPE/MH }\end{array}$ & [67] \\
\hline HDPE & $\mathrm{ATH}, \mathrm{MH}$ & $\begin{array}{l}\text { Endothermic decomposition } \\
\text { reaction and heat absorption }\end{array}$ & $\begin{array}{l}\text {-The HDPE/ATH/MH system } \\
\text { demonstrated the lowest value of } \\
\text { PHR rate } \\
\text {-The lowest amount of THR belonged } \\
\text { to HDPE/ATH/MH system } \\
\text {-Combination of ATH and MH } \\
\text { indicated the significant } \\
\text { non-flammability behavior }\end{array}$ & [68] \\
\hline LDPE & $\mathrm{Zn} / \mathrm{Al}, \mathrm{Ni} / \mathrm{Al}, \mathrm{Co} / \mathrm{Al}$ & Char forming & $\begin{array}{l}\text {-The incorporation of } \mathrm{Zn} / \mathrm{Al}-\mathrm{LDH} \\
\text { and Ni/Al-LDH with LDPE showed } \\
\text { more decrease of flammability } \\
\text { compared to } \\
\text { Co/Al-LDH incorporation } \\
\text {-The composite containing LDH } \\
\text { alternated with organic onions } \\
\text { indicated more flammability } \\
\text { reduction in comparison with } \\
\text { composite containing } \\
\text { inorganic anions }\end{array}$ & [69] \\
\hline LDPE & $\begin{array}{l}\text { ATH, MH, Ferric } \\
\text { oxyhydroxide (FH) }\end{array}$ & $\begin{array}{l}\text { Char forming, Restriction of } \\
\text { oxygen diffusion }\end{array}$ & $\begin{array}{l}\text {-The higher LOI value of composites } \\
\text { containing ATH compared to } \\
\text { composites containing MH and FH } \\
\text {-LDPE/MPP/Starch (ST)/ATH system } \\
\text { indicated the more protective } \\
\text { charred layer with smaller pores on } \\
\text { it compared to other systems }\end{array}$ & [14] \\
\hline LDPE/EVA & $\begin{array}{l}\text { Organopalygorskite } \\
\text { (OPGS), Molybdenum } \\
\text { sulfide }\left(\mathrm{MoS}_{2}\right), \mathrm{MH}\end{array}$ & Char formation & $\begin{array}{l}\text {-Increasing the LOI value }(26 \%) \\
\text {-Reduction in the burning rate }(66 \%) \\
\text { and PHR rate ( } 83 \%) \text { compared neat } \\
\text { polymer blend } \\
\text {-Indicative the UL- } 94 \mathrm{~V}-0 \text { rating }\end{array}$ & [70] \\
\hline Paraffin/HDPE & $\mathrm{MH}, \mathrm{ATH}, \mathrm{EG}$ & Char formation, physical barrier & $\begin{array}{l}\text {-Increasing in thermal stability and } \\
\text { carbonization ability } \\
\text {-Increasing the amount of } \\
\text { char residue } \\
\text {-Reduction in the THR and PHR rate }\end{array}$ & [71] \\
\hline PE/PCS & $\mathrm{MH}$ & $\begin{array}{l}\text { Exert condensed phase, barrier } \\
\text { effects of char formation }\end{array}$ & $\begin{array}{l}\text {-Improving thermal stability } \\
\text {-Forming the multi-layered } \\
\text { char structure }\end{array}$ & [72] \\
\hline EVA/LDPE & $\begin{array}{l}\text { ATH, Magnesium } \\
\text { hydroxide sulfate } \\
\text { hydrate (MHSH) }\end{array}$ & Char forming & $\begin{array}{l}\text {-Improving thermal stability } \\
\text {-Reduction in thermal degradation } \\
\text { rate in the temperature ranges of } \\
410^{\circ} \mathrm{C} \sim 510^{\circ} \mathrm{C} \\
\text {-Indicative V-0 in UL- } 94 \text { test }\end{array}$ & [73] \\
\hline LDPE/EVA & $\begin{array}{l}\text { MH, Keratin fibers } \\
(\mathrm{KF}) \text {, deoxyribose } \\
\text { nucleic acid (DNA) }\end{array}$ & Char forming & $\begin{array}{l}\text {-Increasing the LOI up to } 24.5 \% \\
\text {-Reducing the HRR by } 82 \% \text { compared } \\
\text { to PE/EVA sample with } 55 \text { wt. } \% \mathrm{MH}\end{array}$ & [74] \\
\hline LDPE/EVA & $\mathrm{MH}, \mathrm{TiO}_{2}$ & Char forming & $\begin{array}{l}\text {-Reaching to V-0 with LOI } \\
\text { value of } 24.9 \% \\
\text {-Increasing mass residue from } 5 \mathrm{wt} . \% \\
\text { for blend to } 25 \mathrm{wt} . \% \text { for the } \\
\text { composite containing both FRs } \\
\text {-Increasing tensile strength and } \\
\text { modulus of LDPE/EVA blend from } \\
6.4 \mathrm{MPa} \text { to } 7.1 \mathrm{MPa} \text { and } 127 \mathrm{MPa} \text { to } \\
133 \mathrm{MPa} \text { respectively by } \\
\text { incorporation of both FRs } \\
\text {-Improving impact strength from } 27.8 \\
\text { to } 35.2 \mathrm{KJ} \cdot \mathrm{mm}^{-2}\end{array}$ & [75] \\
\hline
\end{tabular}


Table 3. Cont.

\begin{tabular}{|c|c|c|c|c|}
\hline Polymer Matrix & Additive(s) & Mechanism(s) & Result(s) & Ref. \\
\hline LLDPE & $\mathrm{MH}, \mathrm{SiO}_{2}$ & Char forming & $\begin{array}{l}\text {-Improving thermal degradation } \\
\text { resistance and the LOI value } \\
\text {-Reduction in PHR rate and THR }\end{array}$ & [76] \\
\hline LLDPE & $\begin{array}{c}\text { Huntite and } \\
\text { hydromagnesite }(\mathrm{HH})\end{array}$ & Char forming & $\begin{array}{l}\text {-Increase in value of LOI and } \\
\text { elastic modulus } \\
\text {-Reduction in the horizontal burning } \\
\text { rate, tensile strength, and elongation } \\
\text { at break }\end{array}$ & [77] \\
\hline HDPE/LDPE/Nylon 6 & $\begin{array}{l}\text { MH, MWCNT, } \\
\text { Kenaf fiber }\end{array}$ & Char forming & $\begin{array}{l}\text {-Increasing the tensile strength value } \\
\text { by } 50 \% \text { at } 0.5 / 0.5 \text { wt. } \% \text { loading of } \\
\mathrm{Mg}(\mathrm{OH})_{2} / \mathrm{MWCNT} \text { compared to } \\
\text { composite without filler } \\
\text { - Reduction in PHR rate with addition } \\
\text { of } \mathrm{Mg}(\mathrm{OH})_{2} / \mathrm{MWCNT}\end{array}$ & [78] \\
\hline HDPE/WF & $\begin{array}{c}\text { MH, } \\
\text { 1,2-bis(pentabromophenyl) } \\
\text { ethane, } \\
\text { Aluminum hydroxide }\end{array}$ & Char forming & $\begin{array}{l}\text {-Significant decrease in the HRR } \\
\text { and THR } \\
\text {-Best fire resistance for } \\
\text { composite containing } \\
\text { 1,2-bis(pentabromophenyl) ethane }\end{array}$ & [79] \\
\hline MDPE & $\begin{array}{l}\text { MH, Calcium-based } \\
\text { hydrated minerals }\end{array}$ & $\begin{array}{c}\text { Formation of cohesive } \mathrm{CaCO}_{3} \\
\text { combustion residue }\end{array}$ & $\begin{array}{l}\text {-Reduction in PHR rate for } \\
\text { Ca-based composites } \\
\text {-Generation of an intumescent } \\
\text { mineral residue during the } \\
\text { combustion by calcium hydroxide }\end{array}$ & [80] \\
\hline LDPE & $\begin{array}{l}\text { MH, Montmorillonite } \\
\text { (MMT) }\end{array}$ & Char forming & $\begin{array}{l}\text {-Higher interlayer spacing is } \\
\text { observed for organosilylated clay } \\
\text { (SC1) compared to original MMT } \\
\text {-Improving thermal stability } \\
\text { compared to commercial organoclays }\end{array}$ & [81] \\
\hline LDPE & $\begin{array}{c}\text { Azocyclohexane } \\
\text { (AZO), } \\
\text { Bis(cyclohexylazo } \\
\text { cyclohexylmethane) } \\
\text { (BISAZO), FlameStab }{ }^{\circledR} \\
\text { NOR116, Magnesium } \\
\text { dihydroxide (MDH), } \\
\text { Luvogard MB81/PE }\end{array}$ & $\begin{array}{l}\text { Intumescent char } \\
\text { layer formation }\end{array}$ & $\begin{array}{l}\text {-Better performance in flame } \\
\text { retardancy when using AZO and } \\
\text { BISAZO compared to the } \\
\text { other additives }\end{array}$ & [82] \\
\hline LDPE/EVA & $\begin{array}{l}\text { Hexaphenoxylcyclo } \\
\text { triphosphazene, } \\
\mathrm{Mg}(\mathrm{OH})_{2}, \mathrm{Al}(\mathrm{OH})_{3}\end{array}$ & Char forming & $\begin{array}{l}\text {-Blends showed better flame } \\
\text { retardancy when composited with } \\
\mathrm{Mg}(\mathrm{OH})_{2} \text { and } \mathrm{Al}(\mathrm{OH})_{3} \\
\text {-The maximum specific optical } \\
\text { density is reduced } \\
\text { from } 370.65 \text { to } 91.72 \\
\text {-An increase in the residual volume } \\
\text { and compactness of solid residue } \\
\text { surface layer based on SEM } \\
\text { morphology is observed }\end{array}$ & [83] \\
\hline LDPE & ATH, EVA & Char forming & $\begin{array}{l}\text {-Flame resistance of EVA/LDPE/ATH } \\
\text { blends is slightly enhanced after } \\
\gamma \text {-irradiation } \\
\text {-Increase in the cross-linking density } \\
\text { caused an enhancement in electrical } \\
\text { and thermal properties } \\
-\gamma \text {-irradiation delayed the thermal } \\
\text { degradation process of } \\
\text { EVA/LDPE/ATH blends }\end{array}$ & [84] \\
\hline $\begin{array}{l}\text { LDPE/Cross-linked } \\
\text { polyethylene (XLPE) }\end{array}$ & $\begin{array}{l}\text { MMT, MH, } \\
\text { LDPE-g-MA }\end{array}$ & Char forming & $\begin{array}{l}\text {-The increase in the tensile and } \\
\text { impacts strengths induced by the } \\
\text { addition of clay and LDPE-g-MA } \\
\text {-Thermal stability at high } \\
\text { temperatures is enhanced due to the } \\
\text { increase in char residual } \\
\text { of nanocomposites } \\
\text {-XLPE nanocomposites showed } \\
\text { efficient level of flame retardancy }\end{array}$ & [85] \\
\hline
\end{tabular}


Table 3. Cont.

\begin{tabular}{|c|c|c|c|c|}
\hline Polymer Matrix & Additive(s) & Mechanism(s) & Result(s) & Ref. \\
\hline MDPE/EVA & $\begin{array}{c}\text { MDH, Hydrated lime, } \\
\text { Hydrated } \\
\text { dolomitic limes }\end{array}$ & $\begin{array}{l}\text { Intumescent char } \\
\text { layer formation }\end{array}$ & $\begin{array}{l}\text {-Ca-based MDPE composites } \\
\text { depicted similar rates of PHR with } \\
\text { MDH composite } \\
\text {-Lower PHR rate observed for } \\
\text { Ca-based fillers in EVA compositions } \\
\text {-The formation of an intumescent } \\
\text { cohesive residue in the combustion } \\
\text { process is induced by an effective } \\
\text { role of calcium di-hydroxide }\end{array}$ & [86] \\
\hline HDPE & ATH, ZB & Char forming & $\begin{array}{l}-2 \text { phr organo-clay additive is used to } \\
\text { achieve V0 rating } \\
\text {-FR materials with high } \\
\text { processability and mechanical } \\
\text { properties is obtained when using } \\
\text { HDPE rendering }\end{array}$ & [87] \\
\hline $\begin{array}{l}\text { LLDPE/Ethylene-acrylic } \\
\text { acid (EAA) }\end{array}$ & $\mathrm{MH}$ & Char forming & $\begin{array}{l}\text {-Addition of EAA improved LOI } \\
\text { value of LLDPE/EAA/MH } \\
\text { from } 28 \% \text { to } 30 \% \\
\text {-Reduction of HRR and SPR values } \\
\text { was occurred because of the } \\
\text { acceptable dispersion of MH } \\
\text {-Improvement of thermal oxidative } \\
\text { stability of LLDPE/EAA/MH due to } \\
\text { the EAA presence }\end{array}$ & [88] \\
\hline LLDPE & $\mathrm{CaCO}_{3}, \mathrm{MgCO}_{3}$, Talc & $\begin{array}{l}\text { Intumescent char } \\
\text { layer formation }\end{array}$ & $\begin{array}{l}\text {-HRR peaks were considerably } \\
\text { reduced with incorporation of all } \\
\text { mineral fillers } \\
\text {-Improvement of nanoparticle } \\
\text { dispersion in LLDPE by stearic acid }\end{array}$ & [89] \\
\hline
\end{tabular}

From Table 3, Huntite and hydromagnesite caused a reduction in the tensile strength and elongation of the LLDPE material. Some of the notable additives that must be taken into consideration with regards to the flame retardancy of PE and its grades are the Organopalygorskite (OPGS), Molybdenum sulfide $\left(\mathrm{MoS}_{2}\right)$, and $\mathrm{MH}$, which all resulted in a drastic reduction of peak heat release rate. Furthermore, the addition of $\mathrm{MH}, \mathrm{TiO}_{2}$ and LDPE composites had an excellent fire resistivity and mechanical performance. Aside from Modified MH, all the additives of HDPE produced better results and can therefore be utilized when developing flame retardant strategies for PE.

\subsection{Boron}

In addition to the water-soluble boron compounds including sodium borate (borax), BA, and boron oxide, water-insoluble ones and more commonly ZBs, are widely used as boron-derived FRs, former for application in cellulosic materials and latter in thermoplastics [52]. Boron based FRs possess low cost, high thermal stability, non-toxicity, and ease of handling, which have resulted in their wide use in PE systems [90]. Employment of ZB, with the most commercial importance, not only improves flame retardancy but also helps with the smoke suppression and anti-arcing in condensed phase [52]. Although ZB FRs are often used in halogen-containing systems, it has also been utilized in halogen-free and FR polymers [91]. Based on the studies conducted by Li et al. [92] and $\mathrm{Wu}$ et al. [93], the introduction of ZB into PE systems can result in the increase in residual char and thermal stability improvement. An extensive review of various types of $\mathrm{ZB}$ and their application was conducted recently by David M. Schubert [94]. In the most reported literatures $[95,96]$, boron compounds were used together with other synergistic retardants such as nitrogen, phosphorus, silicon, and other synergies that has been comprehensively investigated in the following section. Therefore, other boron-based FRs, including calcium borate, melamine borate, boron phosphate, ammonium pentaborate, borosiloxane, etc., have become potential candidates only in recent years [52].

Upon heating and polymer combustion, depending on the grades of ZBs, endothermic dehydration occurs, in which the ZB loses its chemically bonded water molecules. This water vaporization not only provides a heat sink, delaying the combustion, but also dilutes the concentration of the oxygen 
and gaseous flammable components in the flame zone, causing an enhancement in the residual char formation [97]. Furthermore, at elevated temperatures, a glassy protective layer may form on the polymer/char surface, acting as a barrier to the transfer of heat, oxygen, and decomposition products, resulting in char strength and further combustion retardant [98]. Hence, another function of the ZB would be inhibiting the oxidation of the char (afterglow suppression), as well as suppressing smoke formation. Accordingly, a change in the oxidative decomposition direction of the halogen-free polymers (e.g., PE) is demonstrated when ZB is used. However, it is hesitated due to the suppression effect of boron oxides on hydrocarbons' decomposition [99], or graphite oxidation in the char [59], or just because of the insulative layer formation. Besides contributing to the condensed phase retardancy, in the presence of halogens, a gas phase flame retardancy is also attributed to the ZB due to the production of halogenated compounds, scavenging hot radicals, during the reaction between $\mathrm{ZB}$ and halogens. It is believed that $\mathrm{BA}$ and $\mathrm{ZB}$ are following the same flame retardancy mechanism just a few studies on flame retardancy effects of BA are released [100,101]. On the other hand, boron oxide can function only in the condensed phase by forming an insulative layer [52].

Recently, Sultigova et al. synthesized a certain chemical composition of $\mathrm{ZB}\left(2 \mathrm{ZnO} \bullet 3 \mathrm{~B}_{2} \mathrm{O}_{3} \bullet 3,5 \mathrm{H}_{2} \mathrm{O}\right)$, using borax and zinc sulfate as the precursors in aqueous solution, aiming at producing composites based on HDPE [102]. The composites were obtained via extrusion of the mixture at several prescribed temperatures. It is found out that the polymeric composites burnt much more slowly, without the formation of polymer melt droplets. Furthermore, the percentage of LOI and coke residue (CR) of the composites was 20.6 and 8.6, respectively, which were much higher than those values for the initial polymer. The results revealed that the incorporation of ZB into HDPE, increased the fire resistance of the starting polymer without diminishing its mechanical properties. Another recent study is developed by Abdulrahman et al. to investigate the effect of $\mathrm{BA}$ and borax on the thermal and viscoelastic properties of natural rubber (NR)/LDPE/high abrasion furnace carbon black composites [103]. For both fillers, the residual char yield was increased in the related composites. The loading of the fillers showed a considerable impact on the flammability behavior of the composites altering it from slow-burning to self-extinguishing (LOI: $28.5 \%$ ) for BA and to the upper range of slow-burning (LOI: $27.8 \%$ ) for borax (Figure 4). Boron-containing FRs can show an advantageous synergistic interaction with MH, phosphorus, carbon, Si- and N- comprising compounds. For instance, Boron phosphate or metal borophosphate are produced in the intumescent systems containing phosphorus compounds (i.e., APP) and $\mathrm{BA}$ or $\mathrm{ZB}$ and boost the char formation and integrity. In the case of boron-nitrogen synergies, generation of boron nitride during fire may change the dominant fire retardancy mode of action. Furthermore, for the boron-nitrogen synergetic systems, it is believed that borosilicate glass or ceramic is formed because of borate/silica fusion at high temperatures. This phenomenon increases the fire resistance in the condensed phase [97]. Other works in the past 10 years on the flame-retardancy of PE using boron compounds have been summarized in Table 4 .

Table 4. Recent studies on flame retardancy of PE using boron and silicon based FRs.

\begin{tabular}{|c|c|c|c|c|}
\hline Polymer Matrix & Additive(s) & Mechanism(s) & Result(s) & Ref. \\
\hline PE & $\begin{array}{l}\text { ZB, Phosphorus-Nitrogen } \\
\text { (DOPO-N) }\end{array}$ & $\begin{array}{l}\text { Exert condensed phase and } \\
\text { gas phase }\end{array}$ & $\begin{array}{l}\text { For the PE/20\%ZB/10\%DOPO-N } \\
\text { composite: } \\
\text {-Increasing in thermal stability } \\
\text {-Reduction in PHR, THR, average heat } \\
\text { combustion, and FGI }\end{array}$ & [104] \\
\hline HDPE & $\begin{array}{c}\text { Fullerene }(\mathrm{C} 60), \\
\text { Decabromodiphenyl } \\
\text { oxide } / \mathrm{Sb}_{2} \mathrm{O}_{3} \\
\text { (brominated FRs) }\end{array}$ & $\begin{array}{c}\text { trapping radical ability in } \\
\text { condensed phase and gaseous } \\
\text { phase by } \mathrm{C} 60 \\
\text { and BFR, respectively }\end{array}$ & $\begin{array}{l}\text {-Improving the thermal and } \\
\text { thermo-oxidative stability of } \\
\text { HDPE/BFR blends by adding C60 } \\
\text {-A remarkable reduction in PHR rate } \\
\text { especially at higher concentration } \\
\text { of C60 }\end{array}$ & [105] \\
\hline
\end{tabular}


Table 4. Cont.

\begin{tabular}{|c|c|c|c|c|}
\hline Polymer Matrix & Additive(s) & Mechanism(s) & Result(s) & Ref. \\
\hline HDPE/WF & $\begin{array}{l}\text { 1,2-bis(pentabromophenyl) } \\
\text { and ethylene } \\
\text { bis(tetrabromophthalimide), } \\
\text { and nanoclay, MAPE } \\
\text { as compatibilizer }\end{array}$ & $\begin{array}{l}\text { Trapping the free radical } \\
\text { produced from WF by } \\
\text { Bromine radicals } \\
\text { Char forming by WF } \\
\text { and nanoclay }\end{array}$ & $\begin{array}{l}\text {-Decreasing the composite strength by } \\
\text { adding FRs } \\
\text {-Synergistic effect in } \\
\text { 1,2-bis(pentabromophenyl)-clay-MAPE } \\
\text { system by reducing PHR rate and } \\
\text { increasing thermal stability }\end{array}$ & [106] \\
\hline HDPE/EVA & $\begin{array}{l}\text { Two different particle } \\
\text { sizes of EG }\end{array}$ & Char forming & $\begin{array}{l}\text {-According to TGA and CCT tests, } \\
\text { thermal stability and fire resistance of } \\
\text { HDPE/EVA blend considerably } \\
\text { increased due to the existence of EG } \\
\text {-EG incorporation decreased the } \\
\text { mechanical properties }\end{array}$ & [108] \\
\hline mLLDPE/(NR/ENR-50) & ZB & Char formation & $\begin{array}{l}\text {-Improvement in crystallinity of all } \\
\text { the blends due to ZB presence and the } \\
\text { best crystallinity was obtained at } 6 \\
\text { phr ZB blend } \\
\text {-Increasing the thermal stability of NR } \\
\text { because of ZB incorporation } \\
\text {-The best thermal stability was } \\
\text { achieved at } 8 \text { phr ZB blend } \\
\text {-Incorporation of ZB enhanced the } \\
\text { LOI value of mLLDPE }\end{array}$ & [109] \\
\hline LLDPE & $\begin{array}{l}\text { Aerosil }{ }^{\circledR} \text { r974 organically } \\
\text { treated fumed silica } \\
\text { (Ar974) in combination } \\
\text { with Al hydroxide Alufy }{ }^{\circledR} \\
2 \text { (AF) or Mg hydroxide } \\
\text { Hydrofy }{ }^{\circledR} \text { G1.5 (HF) }\end{array}$ & Char Formation & $\begin{array}{l}\text {-Both PE/HF/Ar974 composites with } \\
20 \text { wt.\% HF and ( } 2 \text { or } 5 \text { wt. } \% \text { Ar974) } \\
\text { self-extinguished (LOI values were } \\
31.9 \% \text { and } 35.2 \% \text {, respectively) } \\
\text {-Effect of nanosilica on decreasing the } \\
\text { PHR rate is significant in } \\
\text { synergistic systems } \\
\text {-Composite containing } 20 \text { wt. } \% \text { HF } \\
\text { and } 5 \text { wt. } \% \text { Ar } 974 \text { showed best fire } \\
\text { performance based on LOI and CCTs }\end{array}$ & [111] \\
\hline HDPE & $\begin{array}{l}\text { Aminosilane modified } \\
\text { silica in combination } \\
\text { with MWCNT }\end{array}$ & $\begin{array}{l}\text { Char layer formation that can be } \\
\text { promoted by MWCNT }\end{array}$ & $\begin{array}{l}\text {-Composite with } 5 \% \text { MWCNT and no } \\
\text { nanosilica represented the max. value } \\
\text { of LOI: } 26.0 \text { ( } 36.8 \% \text { higher than that of } \\
\text { neat HDPE) and the min. value of the } \\
\text { PHR rate ( } 54 \% \text { reduction) } \\
\text {-Increase in MWCNT loading } \\
\text { decreased PHR rate } \\
\text {-Lowest smoke production for the } \\
\text { composite with only nanosilica and } \\
\text { highest with the ones with } \\
\text { only MWCNT } \\
\text {-Higher MWCNT loading, thicker and } \\
\text { more homogeneous char layer } \\
\text {-Slight synergism between fillers }\end{array}$ & [112] \\
\hline
\end{tabular}


Table 4. Cont.

\begin{tabular}{|c|c|c|c|c|}
\hline Polymer Matrix & Additive(s) & Mechanism(s) & Result(s) & Ref. \\
\hline LDPE & 4A zeolite & $\begin{array}{l}\text { Intumescent char } \\
\text { layer formation }\end{array}$ & $\begin{array}{l}\text {-Enhancement in the LDPE/IFR's } \\
\text { LOI value } \\
\text {-Successful passing in the UL-94 V-0 } \\
\text { rating test for all composites } \\
\text {-Improvement in the strength and } \\
\text { compactness of the char surface }\end{array}$ & [113] \\
\hline LDPE/EVA & Nanoclay, ATH, ZB & Char formation & $\begin{array}{l}\text {-Using nanoclays improved many } \\
\text { parameters of flammability including } \\
\text { ignition time, FGI, and PHR } \\
\text {-Nanoclays effects are intensified } \\
\text { when combined with traditional } \\
\text { aluminum hydroxide or } \\
\text { aluminum hydroxide }\end{array}$ & [115] \\
\hline LDPE & Fe-MMT, Fe-OMMT & $\begin{array}{l}\text { Intumescent char } \\
\text { layer formation }\end{array}$ & $\begin{array}{l}\text {-Lower HRR and lower THR } \\
\text { observed for LDPE/IFR/Fe-MMT } \\
\text { compared to LDPE/IFR/Fe-OMMT for } \\
\text { the same loading percentage }\end{array}$ & [116] \\
\hline HDPE & $\mathrm{APP}, \mathrm{SiO}_{2}$ & Char formation & $\begin{array}{l}\text {-Lower initial temperature and peak } \\
\text { temperature of thermal degradation is } \\
\text { achieved for RPC compared to } \\
\text { wood-HDPE composites (WPC) } \\
\text {-Introducing APP to RPCN expedites } \\
\text { the thermal degradation of RPC } \\
\text {-Better flame retardancy is } \\
\text { observed for RPC }\end{array}$ & [117] \\
\hline Wood fiber-HDPE & Nano-SiO 2 & Char formation & $\begin{array}{l}\text {-Reduced the HRR, THR, and total } \\
\text { smoke release of wood } \\
\text { fiber-HDPE composites } \\
\text {-Tensile and flexural } \\
\text { strength improved }\end{array}$ & [119] \\
\hline HDPE/Wheat straw & $\mathrm{Mg}(\mathrm{OH})_{2}$, Nanoclay & Char formation & $\begin{array}{l}\text {-Increasing the nanoclay and } \\
\mathrm{Mg}(\mathrm{OH})_{2} \text { content reduced the } \\
\text { burning rate, tensile and impact } \\
\text { strength of the samples } \\
\text {-Increasing the nanoclay weight } \\
\text { percentage increased the tensile } \\
\text { modulus and impact strength }\end{array}$ & [120] \\
\hline $\mathrm{PE}$ & MMT, Sepiolite, POSS & Char formation & $\begin{array}{l}\text {-HRR of CaSiEBA significantly } \\
\text { increased after MMT } \\
\text { nanofibers addition } \\
\text {-Flammability retardancy of CaSiEBA } \\
\text { and CaSiEMAA remained unchanged } \\
\text { after sepiolite incorporation } \\
\text {-Reduction of dripping was occurred } \\
\text { due to the addition of only small } \\
\text { amount of POSS } \\
\text {-POSS enhanced HRR value } \\
\text { of CaSiEMAA }\end{array}$ & [121] \\
\hline
\end{tabular}


Table 4. Cont.

\begin{tabular}{|c|c|c|c|c|}
\hline Polymer Matrix & Additive(s) & Mechanism(s) & Result(s) & Ref. \\
\hline PE & $\begin{array}{l}\text { OMMT, } \\
\text { Diphenylmethanamine } \\
\text { spirocyclic pentaerythritol } \\
\text { bisphosphonate (PSPD) }\end{array}$ & $\begin{array}{l}\text { Intumescent char } \\
\text { layer formation }\end{array}$ & $\begin{array}{l}\text {-Combination of PSPD and } \\
\text { montmorillonite (MT) improved the } \\
\text { thermal stability of LDPE } \\
\text {-The flammability of LDPE Extremely } \\
\text { reduced due to the } \\
\text { addition of PSPD/MT } \\
\text {-51\% decrease in the PHR } \\
\text { rate of LDPE/PSPD/OMMT in } \\
\text { comparison with LDPE }\end{array}$ & [122] \\
\hline HDPE & $\begin{array}{c}\text { MH, Aluminium } \\
\text { hydroxide, EG, APP, } \\
\text { PER, MMT }\end{array}$ & Char formation & $\begin{array}{l}\text {-Improved flame retardancy behavior } \\
\text { obtained by using APP/PER/MMT } \\
\text { and APP/EG } \\
\text {-Increasing the thermal stability of } \\
\text { HDPE due to the FRs incorporation }\end{array}$ & [123] \\
\hline
\end{tabular}

(a)
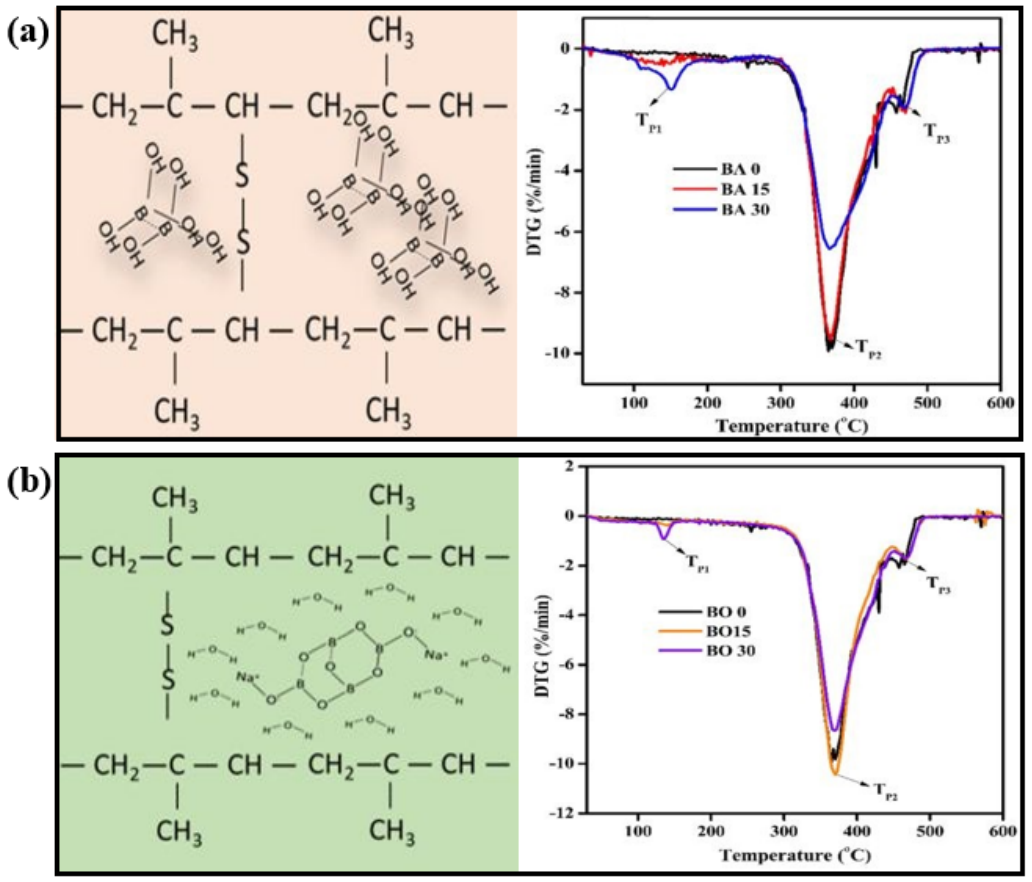

Figure 4. Effect of the boron compound additive on cross-linking and DTG curves of the NR/LDPE/HAF $(100 / 10 / 30)$ with varying loadings (0-30) of (a) BA, and (b) borax (BO), reprinted with permission from Ref. [103].

\subsection{Silicon}

Silicon-containing FRs always have been in the frontline of co-additives in FR systems for PE products due to their high versatility, compatibility, low toxicity, and environmentally friendly characteristics $[47,97]$. This class of compounds can be mainly categorized into silicones, silica, organosilanes, silsesquioxanes, and silicates, functioning in FR systems as additives or other forms $[52,90]$. Silicon-comprising materials are inherently thermal stable and during a fire, they can produce an insulative layer upon decomposition. Through the formation of a highly thermally stable char, further substrate decomposition would be suppressed, and the rate of heat release would be lowered. Thus, the combustion of silicones is only associated with the emission of a negligible amount of toxic gases and smoke [124]. The reduction of HRR, PHR rate in CCT, and the rate of combustibles are most evident in silicone and siloxane. Besides fire retardancy through the condensed phase, the functionalization of silicone-based FRs with phosphorous or nitrogen groups makes them 
more efficient through contribution to the gas phase by trapping of dynamic radicals in the vapor phase $[90,125]$.

Silicon dioxide, known as silica, in forms of silica gel, fumed and fused silica, is the most common silicon-based FR tested in various polymeric matrixes. Employment of functionalized silica and nano-silicates, in which oligomers or polymers attached through silanol groups, is a promising approach to produce the most efficient silicon-based fire retardants. This group of organic silicon compounds attracted intensive attention in recent years and the amount of research introducing these novel additives is growing [81,110]. Scarfato et al. reported the incorporation of a novel SC1 into the LDPE matrix to investigate its thermal and burning behavior together with its synergism with $\mathrm{MH}$ [81]. The SC1 was synthesized through the functionalization of MMT with (3-glycidyloxypropyl) trimethoxysilane (GOPTMS) by a silylation procedure (Figure 5a). LDPE/SC1, $\mathrm{LDPE} / \mathrm{MH}$, and LDPE/SC1/MH composites with various loading of the fillers were prepared. For binary LDPE/8SC1 system, the LOI value increased only from 17.5 up to $18.6 \mathrm{vol} \%$, demonstrating a minor change that may be still within the margin of uncertainty. This is probably because of inadequate protection against direct contact to flames, provided by the inorganic residue layer formed by nanoclays. On the other hand, the addition of SC1 to LDPE/MH composites lowered their LOI indicating an adverse effect on the flame retardancy of the system, which is likely due to the worsening of the protective fire residue quality. Furthermore, with increasing SC1 content in LDPE/SC1 composites, the time to ignition (TTI) was decreased (Figure $5 b$ ).

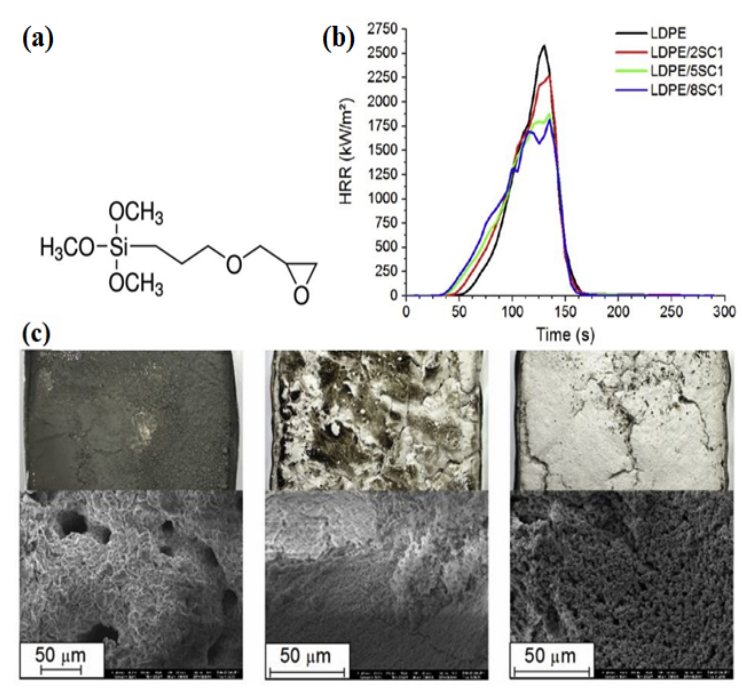

Figure 5. (a) Chemical structure GOPTMS; (b) Burning behavior of the LDPE-based systems in which various loadings of SC1 incorporated; and (c) Surface and microscopic structure of the fire residue in LDPE/SC1, LDPE/MH, and LDPE/SC1/MH composites (from left to right), adapted with permission from Ref. [81].

In addition to the aforementioned organic silicones, noticeable research works have been conducted recently on polydimethylsiloxane (PDMS), as one of the most important polyorganosiloxanes, to modify the fire-resistance properties of organic polymers, through direct mixing with the polymers, deposition of PDMS on the fillers or synthesis of copolymers [126]. Owning to limited thermodynamic miscibility of PE with PDMS, ethylene-methyl acrylate copolymer (EMA) is often used as the chemical compatibilizer in a LDPE-PDMS mixture [127]. A recent review on flame resistance of PDMS systems by Zielecka et al. is a comprehensive reference for more information [124]. Moreover, polyhedral oligomeric silsesquioxane (POSS) with their specific hybrid organic-inorganic structures, also attracted significant attention in recent years [128]. An overview of the fire retardancy properties of polymer/POSS nanocomposites is represented by Zhang et al. [129]. Monofunctional POSS can contribute to the polymerization processes to produce, for instance, PE-POSS, poly(methyl methacrylate)-POSS, or other nanocomposites [130]. 
Whilst the addition of $2.5 \mathrm{wt} . \%$ octamethyl POSS into the PE-calcium carbonate-silicone (CaSiEMAA) composite system showed poor performance in the CCT, it eliminated dripping completely which is likely because of promoting ceramization of the silicon at the surface [121]. In essence, the rich chemistry of silicon compounds, especially, their inherent thermal stability, makes them strong candidates for FR applications. Table 4 shows a summary of recent studies in the past 10 years on PE systems using boron-based FRs.

Table 4 shows that POSS can reduce the dripping effect of PE. Nano clays are effective in extending the ignition times and reducing fire growth capacity, PHR rate as well as increasing the mechanical properties of PEs. The presence of $\mathrm{ZB}$ enhances the crystallinity of PE whiles an increase in the ratio of $\mathrm{BA} / \mathrm{BX}$ has an adverse effect on ignition time, HRR, smoke production rate. It is therefore of great importance to maintain the blends at desirable ratios.

\section{The Role of Nanotechnology in Flame Retardancy of Polymer Nanocomposites}

Nowadays, the most important role of nanomaterials in polymer nanocomposites is the improvement of mechanical properties, such as impact strength and stiffness [131,132]. First, the employment of nanocomposites as FRs is receiving great attention because of nanomaterials with high aspect ratio, and many studies are conducted in this field [133]. Although some of the research in this field indicated improvement of flame retardancy via the incorporation of nanomaterials, some of them showed negative effects of using them [134-136]. Recently, researchers turned to the simultaneous use of nanomaterials and FRs to improve the flammability of polymer nanocomposites. Enormous studies have been conducted about the combination of nanomaterials and FR compounds, which showed synergistic effects in different properties of nanocomposites [137-139]. Exploiting the combination of these nanoscale materials not only reduces the loading of nanomaterials and FR additives but also improves the mechanical and flame retardancy properties simultaneously.

\subsection{The Role of Nanomaterials in Improving Flame Retardancy of PE Systems}

Szustakiewicz et al. investigated on flame retardancy of HDPE/clay nanocomposites with MPP and APP FRs. They used two different types of organoclay: hydrophobic and hydrophilic. Based on the results of two flammability test methods (LOI and CCT), the simultaneous addition of organoclay and FRs to HDPE simultaneously results in a synergistic effect of flame retardancy. In this case, the LOI increases because of two factors, firstly, hydrophobic clay forms a reinforced structure that hinders the heat transfer of heat and secondly, APP intumescent char formation. As a result, the combination of these two effects makes the material burning more slowly [140].

Chuang et al. also found that the incorporation of nano-dispersed layered silicate and low smoke non-halogen (LSNH) FRs to the EVA/HDPE polymer blend caused a synergistic effect on the flame retardancy and smoke suppressing. According to the results, during combustion, the HRR of the FR-EVA/LDPE-n nanocomposite is $40 \%$ lower than the FR-EVA/LDPE polymer blend. Furthermore, they investigated the effect of organoclay contents on the flammability of FR-EVA/LDPE-n. It was found that there is an optimum loading of organoclay ( $3 \mathrm{phr}$ ), where the nanocomposite has the highest performance in flame retardancy [141]. In another study by Yu et al., the effects of adding MWCNTs and $\mathrm{Ni}_{2} \mathrm{O}_{3}$ on the flame retardancy performance of LLDPE were investigated. The results of CCT show a synergistic effect of a combination of MWCNTs and $\mathrm{Ni}_{2} \mathrm{O}_{3}$ in improving the flame retardancy of LLDPE, such that nanocomposite containing $3 \mathrm{wt} . \%$ MWCNTs and $5 \mathrm{wt} . \% \mathrm{Ni}_{2} \mathrm{O}_{3}$ shows $73 \%$ reduction in PHR rate compared to LLDPE and the yield of residual char is $13.7 \%$. The improvement of flame retardancy of LLDPE by incorporating MWCNTs and $\mathrm{Ni}_{2} \mathrm{O}_{3}$ was attributed to the physical effect of MWCNTs (formation of a network like structure because of the good dispersion of MWCNTs), chemical effect of $\mathrm{Ni}_{2} \mathrm{O}_{3}$ (catalytic carbonization), and the combination of physical and chemical effect. Figure 6 schematically illustrates the aforementioned mechanisms [142]. 


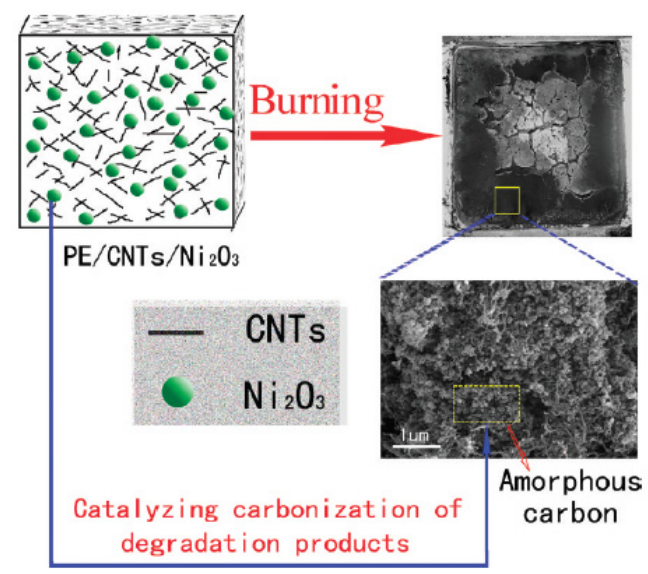

Figure 6. Schematic representation of the synergistic effect mechanism between $\mathrm{Ni}_{2} \mathrm{O}_{3}$ and MWCNTs on enhancing the flame retardancy of LLDPE, reprinted with permission from Ref. [142].

Han et al. applied different contents of well-exfoliated graphene nano-platelets to enhance flame retardancy of polyethylene/alumina trihydrate (PE/ATH) composites and showed the addition of $0.2 \mathrm{wt} . \%$ of GNP decreased the PHR by $18 \%$ of that of the PE/ATH composite. A possible explanation of this behavior is a char layer of GNPs acting as a heat shield and a barrier against mass transport. Images of the PE/ATH/GNPx ( $x$, contents of GNP) after cone testing are represented in Figure 7.
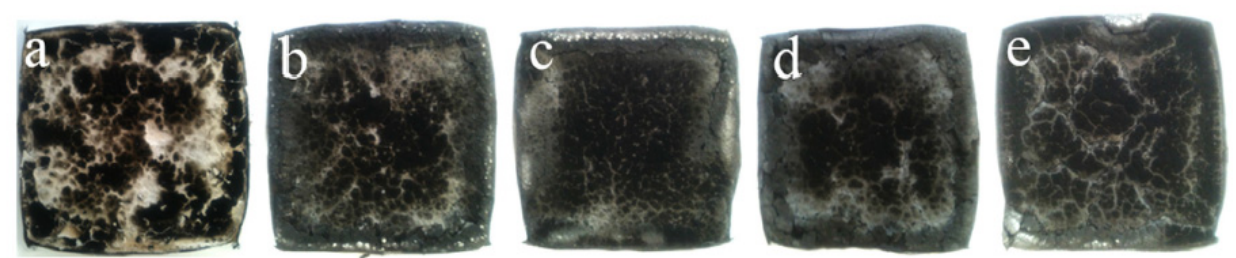

Figure 7. Photos of the residues after cone testing $\left(100 \times 100 \mathrm{~mm}^{2}\right)$ of PE/ATH/GNPx, $(\mathbf{a}), x=0.2(\mathbf{b})$, $x=0.5(\mathbf{c}), x=1.0(\mathbf{d})$, and $x=1.5(\mathbf{e})$, reprinted with permission from Ref. [143].

Table 5 represents some results about the influence of nanomaterials on the flammability of PE nanocomposites.

Table 5. Effects of different types of nanomaterials on the flammability of PE.

\begin{tabular}{|c|c|c|c|}
\hline $\begin{array}{l}\text { Nanomaterial and Its } \\
\text { Loading Amount }\end{array}$ & $\begin{array}{l}\text { Types of FR and } \\
\text { Its Loading }\end{array}$ & Result(s) & Ref. \\
\hline Ce-MWCNTs, 3 wt. $\%$ & $\begin{array}{l}\text { Brominated FR, } \\
10 \mathrm{wt} . \%\end{array}$ & $\begin{array}{l}25 \% \text { reduction in PHR rate observed } \\
\text { from CCT, improved the UL- } 94 \text { from } \\
\text { V-2 to V-0 }\end{array}$ & [144] \\
\hline Nano-SiO ${ }_{2}, 6$ wt. $\%$ & APP, 8 wt. $\%$ & $\begin{array}{l}42 \% \text { and } 44 \% \text { reduction in average } \\
\text { HRR and PHR rate, respectively, } 78 \% \\
\text { increase in TTI }\end{array}$ & [145] \\
\hline $\begin{array}{l}\text { Organic-modified } \\
\text { montmorillonite, } 10 \mathrm{wt} . \%\end{array}$ & MHSH, 30 wt. $\%$ & $\begin{array}{l}84 \% \text { reduction in PHR rate and } \\
\text { increase in } t_{\text {ign }} \text { observed from CCT. }\end{array}$ & [146] \\
\hline $\begin{array}{l}\text { Organic-modified } \\
\text { montmorillonite, } 5 \text { wt. } \%\end{array}$ & IFRs, 15 wt. $\%$ & $\begin{array}{l}51 \% \text { reduction in PHR rate observed } \\
\text { from CCT }\end{array}$ & [122] \\
\hline Halloysite nanotubes, 2 wt.\% & IFRs, 28 wt. $\%$ & $\begin{array}{c}92 \% \text { and } 75 \% \text { decrease in PHR rate and } \\
\text { THR, respectively. }\end{array}$ & [147] \\
\hline Graphene, 1 wt. $\%$ & $\begin{array}{c}\text { Brominated } \\
\text { polystyrene/antimony } \\
\text { trioxide, } 6.2 \mathrm{wt} . \%\end{array}$ & $\begin{array}{l}\text { Increase LOI value from } 23.4 \% \text { to } \\
24.1 \% \text {, change UL- } 94 \text { grades } \\
\text { from NG to V- } 2 \text {. }\end{array}$ & [148] \\
\hline
\end{tabular}




\subsection{Incorporation Methods of Nanomaterials in Polymer Matrices}

A variety of methods are applied for the incorporation of nanomaterials into PE, depending on the nature of the nanomaterials [149]. These methods include in situ polymerization, solvent casting, and melt mixing, which will be elaborated in the following sections.

\subsubsection{In Situ Polymerization}

In this method, at first nanomaterials and monomers are mixed in a solvent with a proper shear rate, which obtains a stable suspension [150]. In this stage, some interfacial agents are added to enhance the stability of the mixture. Then, the obtained mixture is fed to the reactor where the processing conditions mostly are the same applied to the synthesis of the base polymer. When the polymerization is complete, the solvent is removed [151]. This method is used for a wide range of polymer nanocomposites.

\subsubsection{Solvent Casting}

This method is mostly used in cases that there is not enough dispersion of nanomaterials in the polymer [152]. In other words, the thermodynamic affinity between polymer and filler is not favorable for homogeneous dispersion. Therefore, the most important step of this method is the breaking of the agglomerates of nanomaterials, and ultra-sonication is the best method to achieve this goal. This process is especially suitable for the exfoliation of clay layers and thermosetting polymers [153,154]. To conserve dispersed/intercalated/exfoliated structure, some interfacial compatibilizers, such as maleic anhydride grafted polymers, are used.

\subsubsection{Melt Mixing}

Melt compounding is the most common method for the production of nanocomposites because of the simplicity and availability of equipment $[155,156]$. Depending on the amount of the product, internal mixer and twin-screw extruder are used for processing. There are two major methods of feeding for melt compounding: direct and master-batch which the later method is more common. In the master-batch feeding method, first, a concentrated master-batch of filler is prepared and then is diluted in the base polymer [157]. To obtain a good dispersion of filler in polymer and improve compatibility among components, some grafted polymers are utilized [158]. The amount of shear rate, mixing time, temperature, and design of the screw profile can determine the final microstructure and properties of the nanocomposites [159,160].

\section{Summary and Perspective}

Flame retardancy of polymeric materials has become an area of keen interest recently following the rampant fire outbreaks. This research focused on the FRs and different application mechanisms available for the treatment of PE and its grades. In this study, a list of phosphorus, melamine, nitrogen, inorganic hydroxide, boron and silicon-based retardants with their loading amounts and effects on the grades of PE have been presented. The desirable FRs are the additives that presents a balance between fire resistivity and maintaining or improving the mechanical properties of the composite. It was realized from the research that the addition of FRs such as POSS, nanoclays, Organopalygorskite (OPGS), Molybdenum sulfide $\left(\mathrm{MoS}_{2}\right), \mathrm{MH}, \mathrm{TiO}_{2}$, etc., greatly improved the fire and mechanical properties of the PE samples. Possible concerns for future research should be to investigate the effect of FR polymers on the environment. Most of the studies analyzed failed to assess the effects of the additives on the environment. Depending on the lifetime of FR polymers, for the short lifetimes, the biodegradability of polymer is an important issue, and the recyclability of FRs is an important factor for the polymers with a long lifetime. The innovative natural sources for the polymer FR additives are highly recommended possibilities for decreasing environmental issues. Moreover, during burning, some additives of the FRs 
can produce toxic compounds that must be controlled or even substituted. Addressing these concerns will be a step towards the betterment of the circular economy model.

Author Contributions: Methodology, E.R.G., F.K., Z.M., A.S.A., F.M.D., M.K., R.E.N., and A.M.; validation, E.R.G., F.K., R.E.N., O.D., A.M., and S.R.; investigation, E.R.G., F.K., Z.M., A.S.A., F.M.D., and M.K.; writing-original draft preparation, E.R.G., F.K., Z.M., F.M.D., A.S.A., and M.K.; writing-review and editing, E.R.G., F.K., Z.M., F.M.D., A.S.A., M.K., R.E.N., O.D., R.A.M., L.J., Q.X., M.F., and F.B.; supervision, O.D., and S.R. All authors have read and agreed to the published version of the manuscript.

Funding: This research received no external funding.

Conflicts of Interest: The authors declare no conflict of interest.

\section{References}

1. Khanal, S.; Lu, Y.; Ahmed, S.; Ali, M.; Xu, S. Synergistic effect of zeolite 4A on thermal, mechanical and flame retardant properties of intumescent flame retardant HDPE composites. Polym. Test. 2020, 81, 106177. [CrossRef]

2. Das, O.; Capezza, J.A.; Mårtensson, J.; Dong, Y.; Neisiany, E.R.; Pelcastre, L.; Jiang, L.; Xu, Q.; Olsson, T.R.; Hedenqvist, S.M. The Effect of Carbon Black on the Properties of Plasticised Wheat Gluten Biopolymer. Molecules 2020, 25, 2279. [CrossRef] [PubMed]

3. Neisiany, R.E.; Enayati, M.S.; Kazemi-Beydokhti, A.; Das, O.; Ramakrishna, S. Multilayered Bio-Based Electrospun Membranes: A Potential Porous Media for Filtration Applications. Front. Mater. 2020, 7, 67. [CrossRef]

4. Salasinska, K.; Mizera, K.; Celiński, M.; Kozikowski, P.; Borucka, M.; Gajek, A. Thermal properties and fire behavior of polyethylene with a mixture of copper phosphate and melamine phosphate as a novel flame retardant. Fire Saf. J. 2020, 115, 103137. [CrossRef]

5. Das, O.; Neisiany, R.E.; Capezza, A.J.; Hedenqvist, M.S.; Försth, M.; Xu, Q.; Jiang, L.; Ji, D.; Ramakrishna, S. The need for fully bio-based facemasks to counter coronavirus outbreaks: A perspective. Sci. Total Environ. 2020, 736, 139611. [CrossRef] [PubMed]

6. Majka, T.M.; Stachak, P. The studies on the production of polyethylene film with reduced flammability. In Proceedings of the 21st International Electronic Conference on Synthetic Organic Chemistry, Santiago, Spain, 1-30 November 2017.

7. Babu, K.; Rendén, G.; Afriyie Mensah, R.; Kim, N.K.; Jiang, L.; Xu, Q.; Restás, Á.; Esmaeely Neisiany, R.; Hedenqvist, M.S.; Försth, M. A review on the flammability properties of carbon-based polymeric composites: State-of-the-art and future trends. Polymers 2020, 12, 1518. [CrossRef]

8. Lai, X.; Tang, S.; Li, H.; Zeng, X. Flame-retardant mechanism of a novel polymeric intumescent flame retardant containing caged bicyclic phosphate for polypropylene. Polym. Degrad. Stab. 2015, 113, $22-31$. [CrossRef]

9. Wang, D.-Y.; Liu, Y.; Wang, Y.-Z.; Artiles, C.P.; Hull, T.R.; Price, D. Fire retardancy of a reactively extruded intumescent flame retardant polyethylene system enhanced by metal chelates. Polym. Degrad. Stab. 2007, 92, 1592-1598. [CrossRef]

10. Liu, Y.; Wang, D.-Y.; Wang, J.-S.; Song, Y.-P.; Wang, Y.-Z. A novel intumescent flame-retardant LDPE system and its thermo-oxidative degradation and flame-retardant mechanisms. Polym. Adv. Technol. 2008, 19, 1566-1575. [CrossRef]

11. Xu, W.; Zhang, B.; Wang, X.; Wang, G.; Ding, D. The flame retardancy and smoke suppression effect of a hybrid containing $\mathrm{CuMoO} 4$ modified reduced graphene oxide/layered double hydroxide on epoxy resin. J. Hazard. Mater. 2018, 343, 364-375. [CrossRef] [PubMed]

12. Majlingova, A.; Kačíková, D.; Xu, Q.; Jin, C. Current Trends in Flame-Retardant Treatment of Selected Polymers - A Review; Technical University in Zvolen: Zvolen, Slovak Republic, 2018.

13. Lim, K.-S.; Bee, S.-T.; Sin, L.T.; Tee, T.-T.; Ratnam, C.T.; Hui, D.; Rahmat, A.R. A review of application of ammonium polyphosphate as intumescent flame retardant in thermoplastic composites. Compos. Part B Eng. 2016, 84, 155-174. [CrossRef]

14. Gao, H.; Hu, S.; Han, H.; Zhang, J. Effect of different metallic hydroxides on flame-retardant properties of low density polyethylene/melamine polyphosphate/starch composites. J. Appl. Polym. Sci. 2011, 122, 3263-3269. [CrossRef] 
15. Camino, G.; Grassie, N.; McNeill, I.C. Influence of the fire retardant, ammonium polyphosphate, on the thermal degradation of poly(methyl methacrylate). J. Polym. Sci. Polym. Chem. Ed. 1978, 16, 95-106. [CrossRef]

16. Dasari, A.; Yu, Z.-Z.; Cai, G.-P.; Mai, Y.-W. Recent developments in the fire retardancy of polymeric materials. Prog. Polym. Sci. 2013, 38, 1357-1387. [CrossRef]

17. Giri, R.; Nayak, L.; Rahaman, M. Flame and fire retardancy of polymer-based composites. Mater. Res. Innov. 2020, 1-29. [CrossRef]

18. Luyt, A.S.; Malik, S.S.; Gasmi, S.A.; Porfyris, A.; Andronopoulou, A.; Korres, D.; Vouyiouka, S.; Grosshauser, M.; Pfaendner, R.; Brüll, R. Halogen-free flame-retardant compounds. Thermal decomposition and flammability behavior for alternative polyethylene grades. Polymers 2019, 11, 1479. [CrossRef]

19. Kurtz, S.M. UHMWPE Biomaterials Handbook: Ultra High Molecular Weight Polyethylene in Total Joint Replacement and Medical Devices; Academic Press: Oxford, UK, 2009.

20. Hench, L.; Jones, J. Biomaterials, Artificial Organs and Tissue Engineering; Elsevier: Abington, PA, USA, 2005.

21. Li, D.; Zhou, L.; Wang, X.; He, L.; Yang, X. Effect of Crystallinity of Polyethylene with Different Densities on Breakdown Strength and Conductance Property. Materials 2019, 12, 1746. [CrossRef]

22. Wilkie, C.A.; Morgan, A.B. Fire Retardancy of Polymeric Materials; CRC Press: Boca Raton, FL, USA, 2009.

23. Grand, A.F.; Wilkie, C.A. Fire Retardancy of Polymeric Materials; CRC Press: Boca Raton, FL, USA, 2000.

24. Khanal, S.; Zhang, W.; Ahmed, S.; Ali, M.; Xu, S. Effects of intumescent flame retardant system consisting of tris (2-hydroxyethyl) isocyanurate and ammonium polyphosphate on the flame retardant properties of high-density polyethylene composites. Compos. Part A Appl. Sci. Manuf. 2018, 112, 444-451. [CrossRef]

25. Ma, Z.-L.; Wang, X.-L.; Wei, H.-M.; Song, H.-Z. Flame retardation of dibromoneopentyl glycol on intumescent flame-retardant/low-density polyethylene composites. J. Appl. Polym. Sci. 2015, 132, 41244. [CrossRef]

26. Yan, J.; Xu, M. Design, synthesis and application of a highly efficient mono-component intumescent flame retardant for non-charring polyethylene composites. Polym. Bull. 2020, 1-20. [CrossRef]

27. Zhang, T.; Zhang, Y.; Xiao, Z.; Yang, Z.; Zhu, H.; Ju, J.W.; Yan, Z. Development of a novel bio-inspired cement-based composite material to improve the fire resistance of engineering structures. Constr. Build. Mater. 2019, 225, 99-111. [CrossRef]

28. Li, W.; Li, S.; Cheng, Z.; Hu, X.; Yang, W.; Yao, Y. The effect of flame retardant-modified sepiolite nanofibers on thermal degradation and fire retardancy of low-density polyethylene. J. Therm. Anal. Calorim. 2019, 138, 1011-1019. [CrossRef]

29. Cavdar, A.D.; Torun, S.B.; Ertas, M.; Mengeloglu, F. Ammonium zeolite and ammonium phosphate applied as fire retardants for microcrystalline cellulose filled thermoplastic composites. Fire Saf. J. 2019, 107, 202-209. [CrossRef]

30. Qin, R.; Zhang, X.; Kong, F.; Yang, J.; Nie, S. Investigation on novel flame retardant low-density polyethylene composites based on THEIC and MCAPP. J. Polym. Res. 2019, 26, 144. [CrossRef]

31. Hong, H.; Liu, H.; Zhang, H.; He, H.; Liu, T.; Jia, D. Flame retarded polyethylene/wood flour composites with high performances: Satisfying both sides with intumescent flame retardants and synergistic compatibilizers, respectively. Polym. Compos. 2018, 39, 569-579. [CrossRef]

32. Long, J.; Li, S.; Liang, B. Synthesis and properties of a new halogen-free flame retardant for polyethylene. Pigment Resin Technol. 2018, 47, 208-215. [CrossRef]

33. Kruger, H.J.; Focke, W.W.; Mhike, W.; Taute, A.; Roberson, A. Thermal properties of polyethylene flame retarded with expandable graphite and intumescent fire retardant additives. Fire Mater. 2017, 41, 573-586. [CrossRef]

34. Makhlouf, G.; Hassan, M.; Nour, M.; Abdelmonem, Y.; Abdelkhalik, A. A novel intumescent flame retardant: Synthesis and its application for linear low-density polyethylene. Arab. J. Sci. Eng. 2017, 42, 4339-4349. [CrossRef]

35. Hassan, M.; Nour, M.; Abdelmonem, Y.; Makhlouf, G.; Abdelkhalik, A. Synergistic effect of chitosan-based flame retardant and modified clay on the flammability properties of LLDPE. Polym. Degrad. Stab. 2016, 133, 8-15. [CrossRef]

36. Matar, M.; Azambre, B.; Cochez, M.; Vahabi, H.; Fradet, F. Influence of modified mesoporous silica SBA-15 on the flammability of intumescent high-density polyethylene. Polym. Adv. Technol. 2016, 27, 1363-1375. [CrossRef] 
37. Altun, Y.; Doğan, M.; Bayraml, E. The effect of red phosphorus on the fire properties of intumescent pine wood flour-LDPE composites. Fire Mater. 2016, 40, 697-703. [CrossRef]

38. Xu, C.; Jian, W.; Xing, C.; Zhou, H.; Zhao, Y.; Pan, H.; Xiong, X. Flame retardancy and mechanical properties of thermal plastic composite panels made from Tetra Pak waste and high-density polyethylene. Polym. Compos. 2016, 37, 1797-1804. [CrossRef]

39. Li, X.; Yang, B. Synergistic effects of pentaerythritol phosphate nickel salt (PPNS) with ammonium polyphosphate in flame retardant of polyethylene. J. Therm. Anal. Calorim. 2015, 122, 359-368. [CrossRef]

40. Katančić, Z.; Krehula, L.K.; Siročić, A.P.; Grozdanić, V.; Hrnjak-Murgić, Z. Effect of modified nanofillers on fire retarded high-density polyethylene/wood composites. J. Compos. Mater. 2013, 48, 3771-3783. [CrossRef]

41. Kruger, H.J.; Focke, W.W.; Mhike, W.; Taute, A.; Roberson, A.; Ofosu, O. Cone calorimeter study of polyethylene flame retarded with expandable graphite and intumescent fire-retardant additives. J. Fire Sci. 2014, 32, 498-517. [CrossRef]

42. Pan, M.; Mei, C.; Song, Y. A novel fire retardant affects fire performance and mechanical properties of wood flour-high density polyethylene composites. BioResources 2012, 7. [CrossRef]

43. Chen, J.; Wang, J.; Ni, A.; Chen, H.; Shen, P.J.P. Synthesis of a novel phosphorous-nitrogen based charring agent and its application in flame-retardant HDPE/IFR composites. Polymers 2019, 11, 1062. [CrossRef]

44. Makhlouf, G.; Hassan, M.; Nour, M.; Abdel-Monem, Y.K.; Abdelkhalik, A. Evaluation of fire performance of linear low-density polyethylene containing novel intumescent flame retardant. J. Therm. Anal. Calorim. 2017, 130, 1031-1041. [CrossRef]

45. Sanchez-Olivares, G.; Sanchez-Solis, A.; Manero, O.; Pérez-Chávez, R.; Jaramillo, M.; Alongi, J.; Carosio, F.J.M. Improving Mechanical Properties and Reaction to Fire of EVA/LLDPE Blends for Cable Applications with Melamine Triazine and Bentonite Clay. Materials 2019, 12, 2393. [CrossRef] [PubMed]

46. Altun, Y.; Doğan, M.; Bayraml1, E. Flammability and thermal degradation behavior of flame retardant treated wood flour containing intumescent LDPE composites. Eur. J. Wood Wood Prod. 2016, 74, 851-856. [CrossRef]

47. Kausar, A.; Rafique, I.; Anwar, Z.; Muhammad, B. Recent developments in different types of flame retardants and effect on fire retardancy of epoxy composite. Polym. Technol. Eng. 2016, 55, 1512-1535. [CrossRef]

48. Yang, Z.-Z.; Li, J.-Q.; Wang, Z.-Z.; Dong, D.-W.; Qi, X.-R.J.B. Tumor-targeting dual peptides-modified cationic liposomes for delivery of siRNA and docetaxel to gliomas. Biomaterials 2014, 35, 5226-5239. [CrossRef]

49. Russell, L.; Marney, D.; Humphrey, D.; Hunt, A.; Dowling, V.; Cookson, L.J.A.F.; R, W.P.; Corporation, V.D. Combining Fire Retardant and Preservative Systems for Timber Products in Exposed Applications-State of the Art Review; Forest \& Wood Products Australia: Melbourne, Australia, 2007.

50. Levchik, S.; Balabanovich, A.; Levchik, G.; Costa, L.J.F. Effect of melamine and its salts on combustion and thermal decomposition of polyamide 6. Materials 1997, 21, 75-83. [CrossRef]

51. Ray, S.S.; Kuruma, M. Halogen-Free Flame-Retardant Polymers: Next-generation Fillers for Polymer Nanocomposite Applications; Springer: Cham, Switzerland, 2020; Volume 294.

52. Morgan, A.B.; Wilkie, C.A. The Non-Halogenated Flame Retardant Handbook; John Wiley \& Sons Inc.: Hoboken, NJ, USA; Scrivener Publishing LLC.: Salem, MA, USA, 2014.

53. Wilén, C.-E.; Pfaendner, R. Design and utilization of nitrogen containing flame retardants based on $\mathrm{N}$-alkoxyamines, azoalkanes and related compounds. In Polymer Green Flame Retardants; Elsevier: Amsterdam, The Netherlands, 2014; pp. 267-288.

54. Cheng, Y.; Li, J.; He, Y.; Wang, B.; Liu, Y.; Wang, Q.J.P.E. Acidic buffer mechanism of cyclotriphosphazene and melamine cyanurate synergism system flame retardant epoxy resin. Science 2015, 55, 1046-1051. [CrossRef]

55. Wan, L.; Deng, C.; Zhao, Z.-Y.; Chen, H.; Wang, Y.-Z.J.P. Flame Retardation of Natural Rubber: Strategy and Recent Progress. Polymers 2020, 12, 429. [CrossRef]

56. Weil, E.D.; Choudhary, V. Flame-retarding plastics and elastomers with melamine. J. Fire Sci. 1995, 13, $104-126$. [CrossRef]

57. Costa, L.; Camino, G.; Luda di Cortemiglia, M.P. Mechanism of Thermal Degradation of Fire-Retardant Melamine Salts; ACS Publications: Washington, DC, USA, 1990.

58. Liodakis, S.; Tsapara, V.; Agiovlasitis, I.; Vorisis, D. Thermal analysis of Pinus sylvestris L. wood samples treated with a new gel-mineral mixture of short-and long-term fire retardants. Thermochim. Acta 2013, 568, 156-160. [CrossRef]

59. Lewin, M.; Weil, E.D. Mechanisms and modes of action in flame retardancy of polymers. Fire Retard. Mater. 2001, 1, 31-68. 
60. Beyer, G. Nanocomposites-A new concept for flame retardant polymers. Polym. News (USA) 2001, 26, 370-378.

61. Weil, E.; Lewin, M.; Rao, D. A search for an interactive flame retardant system for ethylene-vinyl acetate. In Proceedings of the 15th Conference on Recent Advances in Flame Retardancy of Polymeric Materials, Stamford, CT, USA, 20-22 May 1996.

62. Mouritz, A.P.; Gibson, A.G. Fire Properties of Polymer Composite Materials; Springer Science \& Business Media: Dordrecht, The Netherlands, 2007; Volume 143.

63. Nalawade, P.; Aware, B.; Kadam, V.J.; Hirlekar, R.S. Layered double hydroxides: A review. J. Sci. Ind. Res. 2009, 68, 267-272.

64. Babu, H.V.; Coluccini, C.; Wang, D.Y. 8-Functional layered double hydroxides and their use in fire-retardant polymeric materials. In Novel Fire Retardant Polymers and Composite Materials; Wang, D.-Y., Ed.; Woodhead Publishing: Cambridge, UK, 2017; pp. 201-238. [CrossRef]

65. Bravo-Suárez, J.J.; Páez-Mozo, E.A.; Oyama, S.T. Review of the synthesis of layered double hydroxides: A thermodynamic approach. Química Nova 2004, 27, 601-614. [CrossRef]

66. Arslan, F.; Dilsiz, N. Flame resistant properties of LDPE/PLA blends containing halogen-free flame retardant. J. Appl. Polym. Sci. 2020, 137, 48960. [CrossRef]

67. Cabrera-Álvarez, E.N.; Ramos-deValle, L.F.; Sánchez-Valdes, S.; Candia-García, A.; Soriano-Corral, F.; Ramírez-Vargas, E.; Ibarra-Alonso, M.C.; Patiño-Soto, P. Study of the silane modification of magnesium hydroxide and their effects on the flame retardant and tensile properties of high density polyethylene nanocomposites. Polym. Compos. 2014, 35, 1060-1069. [CrossRef]

68. Beltrán-Ramírez, F.I.; Ramos-deValle, L.F.; Ramírez-Vargas, E.; Sánchez-Valdes, S.; Espinoza-Martínez, A.B.; Martínez-Colunga, J.G.; Rodríguez-Fernandez, O.S.; Cabrera-Alvarez, E.N.; López-Quintanilla, M.L. Effect of Nanometric Metallic Hydroxides on the Flame Retardant Properties of HDPE Composites. J. Nanomater. 2014, 2014, 969184. [CrossRef]

69. Jaerger, S.; Wypych, F. Thermal and flammability properties influenced by Zn/Al, Co/Al, and Ni/Al layered double hydroxide in low-density polyethylene nanocomposites. J. Appl. Polym. Sci. 2020, 137, 48737. [CrossRef]

70. Sánchez-Valdes, S.; Ramírez-Vargas, E.; Rodriguez-Gonzalez, J.A.; Uribe-Calderón, J.A.; Ramos de-Valle, L.F.; Zuluaga-Parra, J.D.; Martínez-Colunga, J.G.; Solís-Rosales, S.G.; Sánchez-Martínez, A.C.; Flores-Flores, R. Organopalygorskite and Molybdenum Sulfide Combinations to Produce Mechanical and Processing Enhanced Flame-Retardant PE/EVA Blend Composites with Low Magnesium Hydroxide Loading. J. Vinyl Addit. Technol. 2020. [CrossRef]

71. Zhou, R.; Ming, Z.; He, J.; Ding, Y.; Jiang, J. Effect of Magnesium Hydroxide and Aluminum Hydroxide on the Thermal Stability, Latent Heat and Flammability Properties of Paraffin/HDPE Phase Change Blends. Polymers 2020, 12, 180. [CrossRef]

72. Wang, C.; Liu, J.; Wang, Y.; Han, Z. Enhanced flame retardance in polyethylene/magnesium hydroxide/polycarbosilane blends. Mater. Chem. Phys. 2020, 253, 123373. [CrossRef]

73. Liu, Z.; Wu, C.; Liu, X.; Chen, X.; Xiang, Y.; Shao, H. Flammability and mechanical properties of EVA/LDPE blended with MHSH whiskers and ATH. Mater. Res. Express 2019, 6, 095319. [CrossRef]

74. Albite-Ortega, J.; Sánchez-Valdes, S.; Ramirez-Vargas, E.; Nuñez-Figueredo, Y.; deValle, L.R.; Martínez-Colunga, J.; Graciano-Verdugo, A.; Sanchez-Martínez, Z.; Espinoza-Martínez, A.; Rodriguez-Gonzalez, J. Influence of keratin and DNA coating on fire retardant magnesium hydroxide dispersion and flammability characteristics of PE/EVA blends. Polym. Degrad. Stab. 2019, 165, 1-11. [CrossRef]

75. Afzal, A.; Usama, M.; Rashid, I.A.; Khalid, Z.; Mohsin, M.; Shakir, M.F.; Tariq, A. Effect of MgOH/TiO2 on flame retardancy and mechanical behavior of composite. Mater. Res. Express 2020, 6, 125352. [CrossRef]

76. Dorigato, A.; Fredi, G.; Fambri, L.; Lopez-Cuesta, J.-M.; Pegoretti, A. Polyethylene-based single polymer laminates: Synergistic effects of nanosilica and metal hydroxides. J. Reinf. Plast. Compos. 2019, 38, 62-73. [CrossRef]

77. Savas, L.A.; Arslan, C.; Hacioglu, F.; Dogan, M. Effect of reactive and nonreactive surface modifications and compatibilizer use on mechanical and flame-retardant properties of linear low-density polyethylene filled with huntite and hydromagnesite mineral. J. Therm. Anal. Calorim. 2018, 134, 1657-1666. [CrossRef] 
78. Ameen Khan, M.; Sailaja, R. Nanocomposites of HDPE/LDPE/Nylon 6 reinforced with MWCNT, Kenaf fiber, nano $\mathrm{Mg}(\mathrm{OH})_{2}$, and PEPA with enhanced mechanical, thermal, and flammability characteristics. Polym. Compos. 2018, 39, E1474-E1486. [CrossRef]

79. Zhang, J.; Mei, C.; Huang, R.; Xu, X.; Lee, S.; Kim, B.J.; Wu, Q. Comparative mechanical, fire-retarding, and morphological properties of high-density polyethylene/(wood flour) composites with different flame retardants. J. Vinyl Addit. Technol. 2018, 24, 3-12. [CrossRef]

80. Laoutid, F.; Lorgouilloux, M.; Bonnaud, L.; Lesueur, D.; Dubois, P. Fire retardant behaviour of halogen-free calcium-based hydrated minerals. Polym. Degrad. Stab. 2017, 136, 89-97. [CrossRef]

81. Scarfato, P.; Incarnato, L.; Di Maio, L.; Dittrich, B.; Schartel, B. Influence of a novel organo-silylated clay on the morphology, thermal and burning behavior of low density polyethylene composites. Compos. Part B Eng. 2016, 98, 444-452. [CrossRef]

82. Pawelec, W.; Tirri, T.; Aubert, M.; Häggblom, E.; Lehikoinen, T.; Skåtar, R.; Pfaendner, R.; Wilén, C.-E. Toward halogen-free flame resistant polyethylene extrusion coated paper facings. Prog. Org. Coat. 2015, 78, 67-72. [CrossRef]

83. Zhao, Z.; Zhou, Z.; Yu, F.; Ji, J. Synthesis and Flame Retardant Properties of Low Density Polyethylene/Ethylene-Vinyl Acetate/Polyphosphazene Derivative Composites. Asian J. Chem. 2015, 27, 919-924. [CrossRef]

84. Zhou, S.; Ning, M.; Wang, X.; Yan, Z.; Guo, D.; He, Q.; Zhang, Y.; She, S.; Hu, Y. The influence of $\gamma$-irradiation on the mechanical, thermal degradation, and flame retardant properties of EVA/LDPE/ATH blends. J. Therm. Anal. Calorim. 2015, 119, 167-173. [CrossRef]

85. Liu, S.-P. Flame retardant and mechanical properties of polyethylene/magnesium hydroxide/montmorillonite nanocomposites. J. Ind. Eng. Chem. 2014, 20, 2401-2408. [CrossRef]

86. Laoutid, F.; Lorgouilloux, M.; Lesueur, D.; Bonnaud, L.; Dubois, P. Calcium-based hydrated minerals: Promising halogen-free flame retardant and fire resistant additives for polyethylene and ethylene vinyl acetate copolymers. Polym. Degrad. Stab. 2013, 98, 1617-1625. [CrossRef]

87. Sanchez-Olivares, G.; Sanchez-Solis, A.; Calderas, F.; Medina-Torres, L.; Herrera-Valencia, E.E.; Castro-Aranda, J.I.; Manero, O.; Di Blasio, A.; Alongi, J. Flame retardant high density polyethylene optimized by on-line ultrasound extrusion. Polym. Degrad. Stab. 2013, 98, 2153-2160. [CrossRef]

88. Liu, J.; Zhang, Y. Effect of ethylene-acrylic acid copolymer on flame retardancy and properties of LLDPE/EAA/MH composites. Polym. Degrad. Stab. 2011, 96, 2215-2220. [CrossRef]

89. Bellayer, S.P.; Tavard, E.; Duquesne, S.; Piechaczyk, A.; Bourbigot, S. Natural mineral fire retardant fillers for polyethylene. Fire Mater. 2011, 35, 183-192. [CrossRef]

90. Popescu, C.-M.; Pfriem, A. Treatments and modification to improve the reaction to fire of wood and wood based products-An overview. Fire Mater. 2020, 44, 100-111. [CrossRef]

91. Levchik, S.V. Introduction to flame retardancy and polymer flammability. In Flame Retardant Polymer Nanocomposites; John Wiley \& Sons: Hoboken, NJ, USA, 2007; pp. 1-29. [CrossRef]

92. Li, S.; Long, B.; Wang, Z.; Tian, Y.; Zheng, Y.; Zhang, Q. Synthesis of hydrophobic zinc borate nanoflakes and its effect on flame retardant properties of polyethylene. J. Solid State Chem. 2010, 183, 957-962. [CrossRef]

93. Wu, Z.; Hu, Y.; Shu, W. Effect of ultrafine zinc borate on the smoke suppression and toxicity reduction of a low-density polyethylene/intumescent flame-retardant system. J. Appl. Polym. Sci. 2010, 117, 443-449. [CrossRef]

94. Schubert, D.M. Hydrated Zinc Borates and Their Industrial Use. Molecules 2019, 24, 2419. [CrossRef]

95. Yalinkilic, M.K.; Su, W.-Y.; Imamyra, Y.; Takahashi, M.; Demirci, Z.; Yallnkilic, A. Boron effect on decay resistance of some fire-retardant coatings applied on plywood surface. Holz als Roh-und Werkstoff 1998, 56, 347-353. [CrossRef]

96. Pang, X.-Y.; Ming-Wei, D.; ZHI-XIAO, Z.; Yu, T. An intumescent flame retardant-expandable graphite: Preparation, characteristics and flame retardance for polyethylene. Kuwait J. Sci. 2015, 42, 133-149.

97. Ciesielski, M.; Burk, B.; Heinzmann, C.; Döring, M. Fire-retardant high-performance epoxy-based materials. In Novel Fire Retardant Polymers and Composite Materials; Woodhead Publishing Elsevier Witney: Oxford, UK, 2017; pp. 3-51.

98. Xue, E.; Zeng, M. Flame Retardant Science and Application; National Defense Industrial Press: Beijing, China, 1988. 
99. Youming, Y.; Xichang, S.; Ruirong, Z. Flame Retardancy Behavior of Zinc Borate. J. Fire Sci. 1999, 17, $355-361$. [CrossRef]

100. Nyambo, C.; Kandare, E.; Wilkie, C. Thermal stability and flammability characteristics of ethylene vinyl acetate (EVA) composites blended with a phenyl phosphonate-intercalated layered double hydroxide (LDH), melamine polyphosphate and/or boric acid. Polym. Degrad. Stab. 2009, 94, 513-520. [CrossRef]

101. Demirel, M.; Pamuk, V.; Dilsiz, N. Investigation of flame retardancy and physical-mechanical properties of zinc borate/boric acid polyester composites. J. Appl. Polym. Sci. 2010, 115, 2550-2555. [CrossRef]

102. Sultygova, Z.K.; Kitieva, L.; Borukaev, T.A. Using Zinc Borate as Effective Flame Retardant. Proc. Key Eng. Mater. 2019, 816, 129-133. [CrossRef]

103. Abdulrahman, S.T.; Ahmad, Z.; Thomas, S.; Maria, H.J.; Rahman, A. Viscoelastic and thermal properties of natural rubber low-density polyethylene composites with boric acid and borax. J. Appl. Polym. Sci. 2020, 137, 49372. [CrossRef]

104. Ai, L.; Yang, L.; Hu, J.; Chen, S.; Zeng, J.; Liu, P. Synergistic Flame Retardant Effect of Organic Phosphorus-Nitrogen and Inorganic Boron Flame Retardant on Polyethylene. Polym. Eng. Sci. 2020, 60, 414-422. [CrossRef]

105. Guo, Z.; Zhao, L.; Fang, Z. The flame retardant and smoke suppression effect of fullerene by trapping radicals in decabromodiphenyl oxide/ $\mathrm{Sb}_{2} \mathrm{O}_{3}$ flame-retarded high density polyethylene. Fire Mater. 2017, 41, 916-924. [CrossRef]

106. Zhang, J.; Wu, Q.; Li, G.; Li, M.-C.; Sun, X.; Ring, D. Synergistic influence of halogenated flame retardants and nanoclay on flame performance of high density polyethylene and wood flour composites. RSC Adv. 2017, 7, 24895-24902. [CrossRef]

107. Wu, G.-F.; Xu, M. Effects of Boron Compounds on the Mechanical and Fire Properties of Wood-chitosan and High-density Polyethylene Composites. BioResources 2014, 9, 4173-4193. [CrossRef]

108. Sun, Z.; Ma, Y.; Xu, Y.; Chen, X.; Chen, M.; Yu, J.; Hu, S.; Zhang, Z. Effect of the particle size of expandable graphite on the thermal stability, flammability, and mechanical properties of high-density polyethylene/ethylene vinyl-acetate/expandable graphite composites. Polym. Eng. Sci. 2014, 54, 1162-1169. [CrossRef]

109. Alwaan, I.M.; Hassan, A. Effects of zinc borate loading on thermal stability, flammability, crystallization properties of magnesium oxide/(90/10) mLLDPE/(NR/ENR-50) blends. Iran. Polym. J. 2014, 23, 277-287. [CrossRef]

110. Nour, M.; Elmorsy, S.; Saltout, R.; El-Gendy, A.A. Fire Behavior of HDPE Composite Based on Modified Clay with Phenol Formaldehyde Silane Resin. Arab. J. Sci. Eng. 2017, 42, 153-162. [CrossRef]

111. Fredi, G.; De Col, A.; Dorigato, A.; Lopez-Cuesta, J.-M.; Fambri, L.; Pegoretti, A. Combined effect of fumed silica and metal hydroxides as fire retardants in PE single-polymer composites. AIP Conf. Proc. 2018, 1981, 020021.

112. Praveen, T.; Sundara Rajan, J.; Sailaja, R. Evaluation of thermal and flame properties of HDPE-MWCNT-SiO2 nanocomposites. Compos. Interfaces 2017, 24, 215-232. [CrossRef]

113. Feng, C.; Liang, M.; Jiang, J.; Huang, J.; Liu, H. Flame retardancy and thermal degradation behavior of efficient intumescent flame retardant LDPE composite containing 4A zeotile. J. Anal. Appl. Pyrolysis 2016, 118, 9-19. [CrossRef]

114. Kratofil Krehula, L.; Katančić, Z.; Marić, G.; Hrnjak-Murgić, Z. Study of Fire Retardancy and Thermal and Mechanical Properties of HDPE-Wood Composites. J. Wood Chem. Technol. 2015, 35, 412-423. [CrossRef]

115. Kaynak, C.; Ibibikcan, E. Contribution of nanoclays to the flame retardancy of polyethylene-based cable insulation materials with aluminum hydroxide and zinc borate. J. Fire Sci. 2013, 32, 121-144. [CrossRef]

116. Deng, C.; Zhao, J.; Deng, C.-L.; Lv, Q.; Chen, L.; Wang, Y.-Z. Effect of two types of iron MMTs on the flame retardation of LDPE composite. Polym. Degrad. Stab. 2014, 103, 1-10. [CrossRef]

117. Pan, M.; Mei, C.; Li, G.; Du, J. Ammonium polyphosphate improving physicochemical properties of rice straw-high density polyethylene composites. Trans. Chin. Soc. Agric. Eng. 2014, 30, 328-333.

118. Chen, S.; Sun, B.; Huang, G.; Guo, H.; Wang, S. Effects of an (Intumescent flame retardant)-montmorillonite combination on the thermal stability and fire-retardant properties of LDPE/EVA nanocomposites. J. Vinyl Addit. Technol. 2013, 19, 285-292. [CrossRef]

119. Mingzhu, P.; Hailan, L.; Changtong, M. Flammability of nano silicon dioxide-wood fiber-polyethylene composites. J. Compos. Mater. 2012, 47, 1471-1477. [CrossRef] 
120. Liany, Y.; Tabei, A.; Farsi, M.; Madanipour, M. Effect of nanoclay and magnesium hydroxide on some properties of HDPE/wheat straw composites. Fibers Polym. 2013, 14, 304-310. [CrossRef]

121. Karlsson, L.; Lundgren, A.; Jungqvist, J.; Hjertberg, T.J.F. Effect of nanofillers on the flame retardant properties of a polyethylene-calcium carbonate-silicone elastomer system. Fire Mater. 2011, 35, 443-452. [CrossRef]

122. Huang, G.; Zhu, B.; Shi, H. Combination effect of organics-modified montmorillonite with intumescent flame retardants on thermal stability and fire behavior of polyethylene nanocomposites. J. Appl. Polym. Sci. 2011, 121, 1285-1291. [CrossRef]

123. Sittisart, P.; Farid, M.M. Fire retardants for phase change materials. Appl. Energy 2011, 88, 3140-3145. [CrossRef]

124. Zielecka, M.; Rabajczyk, A.; Pastuszka, Ł.; Jurecki, L.J.C. Flame Resistant Silicone-Containing Coating Materials. Coatings 2020, 10, 479. [CrossRef]

125. Alongi, J.; Colleoni, C.; Rosace, G.; Malucelli, G. Phosphorus-and nitrogen-doped silica coatings for enhancing the flame retardancy of cotton: Synergisms or additive effects? Polym. Degrad. Stab. 2013, 98, 579-589. [CrossRef]

126. Serra, A.; Ramis, X.; Fernández-Francos, X. Epoxy Sol-Gel Hybrid Thermosets. Coatings 2016, 6, 8. [CrossRef]

127. Jana, R.; Mukunda, P.; Nando, G. Thermogravimetric analysis of compatibilized blends of low density polyethylene and poly (dimethyl siloxane) rubber. Polym. Degrad. Stab. 2003, 80, 75-82. [CrossRef]

128. Rezakazemi, M.; Vatani, A.; Mohammadi, T. Synergistic interactions between POSS and fumed silica and their effect on the properties of crosslinked PDMS nanocomposite membranes. RSC Adv. 2015, 5, 82460-82470. [CrossRef]

129. Zhang, W.; Camino, G.; Yang, R. Polymer/polyhedral oligomeric silsesquioxane (POSS) nanocomposites: An overview of fire retardance. Prog. Polym. Sci. 2017, 67, 77-125. [CrossRef]

130. Waddon, A.; Zheng, L.; Farris, R.; Coughlin, E.B. Nanostructured polyethylene-POSS copolymers: Control of crystallization and aggregation. Nano Lett. 2002, 2, 1149-1155. [CrossRef]

131. Sun, D.; Yang, C.; Qi, X.; Yang, J.; Wang, Y. Largely enhanced fracture toughness of the PP/EPDM blends induced by adding carbon nanofibers. Compos. Sci. Technol. 2018, 164, 146-152. [CrossRef]

132. Rezvani Ghomi, E.; Esmaeely Neisiany, R.; Nouri Khorasani, S.; Dinari, M.; Ataei, S.; Koochaki, M.S.; Ramakrishna, S. Development of an epoxy self-healing coating through the incorporation of acrylic acid-co-acrylamide copolymeric gel. Prog. Org. Coat. 2020, 149, 105948. [CrossRef]

133. Kashiwagi, T.; Du, F.; Douglas, J.F.; Winey, K.I.; Harris, R.H.; Shields, J.R. Nanoparticle networks reduce the flammability of polymer nanocomposites. Nat. Mater. 2005, 4, 928-933. [CrossRef]

134. Peeterbroeck, S.; Laoutid, F.; Taulemesse, J.M.; Monteverde, F.; Lopez-Cuesta, J.M.; Nagy, J.B.; Alexandre, M.; Dubois, P. Mechanical properties and flame-retardant behavior of ethylene vinyl acetate/high-density polyethylene coated carbon nanotube nanocomposites. Adv. Funct. Mater. 2007, 17, 2787-2791. [CrossRef]

135. Cai, G.; Dasari, A.; Yu, Z.-Z.; Du, X.; Dai, S.; Mai, Y.-W.; Wang, J. Fire response of polyamide 6 with layered and fibrillar nanofillers. Polym. Degrad. Stab. 2010, 95, 845-851. [CrossRef]

136. Dasari, A.; Yu, Z.-Z.; Mai, Y.-W.; Cai, G.; Song, H. Roles of graphite oxide, clay and POSS during the combustion of polyamide 6. Polymer 2009, 50, 1577-1587. [CrossRef]

137. Liu, S.; Fang, Z.; Yan, H.; Chevali, V.S.; Wang, H. Synergistic flame retardancy effect of graphene nanosheets and traditional retardants on epoxy resin. Compos. Part A Appl. Sci. Manuf. 2016, 89, 26-32. [CrossRef]

138. Gao, Y.; Zhang, Y.; Williams, G.R.; O'Hare, D.; Wang, Q. Layered double hydroxide-oxidized carbon nanotube hybrids as highly efficient flame retardant nanofillers for polypropylene. Sci. Rep. 2016, 6, 35502. [CrossRef]

139. Huang, G.; Chen, S.; Song, P.; Lu, P.; Wu, C.; Liang, H. Combination effects of graphene and layered double hydroxides on intumescent flame-retardant poly (methyl methacrylate) nanocomposites. Appl. Clay Sci. 2014, 88, 78-85. [CrossRef]

140. Szustakiewicz, K.; Cichy, B.; Gazińska, M.; Pigłowski, J. Comparative study on flame, thermal, and mechanical properties of HDPE/clay nanocomposites with MPP or APP. J. Reinf. Plast. Compos. 2013, 32, 1005-1017. [CrossRef]

141. Chuang, T.-H.; Guo, W.; Cheng, K.-C.; Chen, S.-W.; Wang, H.-T.; Yen, Y.-Y. Thermal properties and flammability of ethylene-vinyl acetate copolymer/montmorillonite/polyethylene nanocomposites with flame retardants. J. Polym. Res. 2004, 11, 169-174. [CrossRef] 
142. Yu, H.; Liu, J.; Wang, Z.; Jiang, Z.; Tang, T. Combination of carbon nanotubes with $\mathrm{Ni}_{2} \mathrm{O}_{3}$ for simultaneously improving the flame retardancy and mechanical properties of polyethylene. J. Phys. Chem. C 2009, 113, 13092-13097. [CrossRef]

143. Han, Z.; Wang, Y.; Dong, W.; Wang, P. Enhanced fire retardancy of polyethylene/alumina trihydrate composites by graphene nanoplatelets. Mater. Lett. 2014, 128, 275-278. [CrossRef]

144. Ran, S.; Guo, Z.; Chen, C.; Zhao, L.; Fang, Z. Carbon nanotube bridged cerium phenylphosphonate hybrids, fabrication and their effects on the thermal stability and flame retardancy of the HDPE/BFR composite. J. Mater. Chem. A 2014, 2, 2999-3007. [CrossRef]

145. Pan, M.; Mei, C.; Du, J.; Li, G. Synergistic effect of nano silicon dioxide and ammonium polyphosphate on flame retardancy of wood fiber-polyethylene composites. Compos. Part A Appl. Sci. Manuf. 2014, 66, 128-134. [CrossRef]

146. Lu, H.; Hu, Y.; Xiao, J.; Wang, Z.; Chen, Z.; Fan, W. Magnesium hydroxide sulfate hydrate whisker flame retardant polyethylene/montmorillonite nanocomposites. J. Mater. Sci. 2006, 41, 363-367. [CrossRef]

147. Zhao, J.; Deng, C.L.; Du, S.L.; Chen, L.; Deng, C.; Wang, Y.Z. Synergistic flame-retardant effect of halloysite nanotubes on intumescent flame retardant in LDPE. J. Appl. Polym. Sci. 2014, 131, 40065. [CrossRef]

148. Ran, S.; Chen, C.; Guo, Z.; Fang, Z. Char barrier effect of graphene nanoplatelets on the flame retardancy and thermal stability of high-density polyethylene flame-retarded by brominated polystyrene. J. Appl. Polym. Sci. 2014, 131, 40520. [CrossRef]

149. Visakh, P.; Yoshihiko, A. Flame Retardants: Polymer Blends, Composites and Nanocomposites; Springer: Cham, Switzerland, 2015.

150. Ajayan, P.M.; Schadler, L.S.; Braun, P.V. Nanocomposite Science and Technology; John Wiley \& Sons: Weinheim, Germany, 2006.

151. Aslzadeh, M.M.; Mir Mohamad Sadeghi, G.; Abdouss, M. Synthesis and characterization of chlorinecontaining flame-retardant polyurethane nanocomposites via in situ polymerization. J. Appl. Polym. Sci. 2012, 123, 437-447. [CrossRef]

152. Chung, D.D. Composite Materials: Science and Applications; Springer: London, UK, 2010.

153. Kuila, B.K.; Nandi, A.K. Physical, mechanical, and conductivity properties of poly (3-hexylthiophene)montmorillonite clay nanocomposites produced by the solvent casting method. Macromolecules 2004, 37, 8577-8584. [CrossRef]

154. Wang, Q.; Dai, J.; Li, W.; Wei, Z.; Jiang, J. The effects of CNT alignment on electrical conductivity and mechanical properties of SWNT/epoxy nanocomposites. Compos. Sci. Technol. 2008, 68, 1644-1648. [CrossRef]

155. Utracki, L.A.; Wilkie, C.A. Polymer Blends Handbook; Springer: Dordrecht, The Netherlands, $2002 ;$ Volume 1.

156. Tadmor, Z.; Gogos, C.G. Principles of Polymer Processing; John Wiley \& Sons: Hoboken, NJ, USA, 2013.

157. Markarian, J. Flame retardants for polyamides-new developments and processing concerns. Plast. Addit. Compd. 2005, 7, 22-25. [CrossRef]

158. Ghomi, E.R.; Khorasani, S.N.; Kichi, M.K.; Dinari, M.; Ataei, S.; Enayati, M.H.; Koochaki, M.S.; Neisiany, R.E. Synthesis and characterization of $\mathrm{TiO}_{2}$ /acrylic acid-co-2-acrylamido-2-methyl propane sulfonic acid nanogel composite and investigation its self-healing performance in the epoxy coatings. Colloid Polym. Sci. 2020, 298, 213-223. [CrossRef]

159. Huang, Y.Y.; Terentjev, E.M. Dispersion of carbon nanotubes: Mixing, sonication, stabilization, and composite properties. Polymers 2012, 4, 275-295. [CrossRef]

160. Kasaliwal, G.; Villmow, T.; Pegel, S.; Pötschke, P. Influence of material and processing parameters on carbon nanotube dispersion in polymer melts. In Polymer-Carbon Nanotube Composites; Elsevier: Amsterdam, The Netherlands, 2011; pp. 92-132.

Publisher's Note: MDPI stays neutral with regard to jurisdictional claims in published maps and institutional affiliations.

(C) 2020 by the authors. Licensee MDPI, Basel, Switzerland. This article is an open access article distributed under the terms and conditions of the Creative Commons Attribution (CC BY) license (http://creativecommons.org/licenses/by/4.0/). 